Doświadczenie mistyczne w religiach niechrześcijańskich.

Perspektywa filozoficzna „Filozofia Chrześcijańska” 17 (2020), s. 19-51

\author{
MATEUSZ STRÓŻYŃSKI \\ Uniwersytet im. Adama Mickiewicza w Poznaniu \\ Wydział Filologii Polskiej i Klasycznej
}

\title{
Samopoznanie umysłu w chrześcijaństwie i buddyzmie
}

Istnieje pewna grupa chrześcijan, którzy są żywo zainteresowani praktyką buddyjskiej medytacji - najczęściej pewnymi formami zokcydentalizowanego zen, ale niekiedy także praktykami innych nurtów buddyzmu - tybetańskimi (wadżrajaną) czy vipassaną (therawadą). Grupa ta niekiedy doświadcza duchowego napięcia w stosunku do nauczania Kościoła katolickiego i obecnych w tradycji chrześcijańskiej bardziej katafatycznych form praktyki duchowej, zakładających użycie wyobraźni, myślenia dyskursywnego i aktów woli podczas modlitwy i medytacji. Najbardziej otwarta na chrześcijan szerzej ludzi Zachodu wydaje się japońska szkoła Sanbo Kyodan, która zminimalizowała elementy religijne i rytualne na rzecz ,czystej” praktyki niedyskursywnej medytacji, rozumianej jako ćwiczenie i doświadczenie niemal wolne od kontekstów religijnych i kulturowych. Do formalnie uznanych przez tę szkołę mistrzów zen należy wielu katolików, a nawet osób duchownych, jak Hugo Ennomiya-Lassale SJ, Willigis Jaeger OSB, Jef Boeckmans OCSO, s. Elaine McInnes (zgromadzenie „Our Lady’s Missionaries”), Ruben Habito (były jezuita) i Robert Kennedy SJ.

W inny sposób zainspirowane praktyką dalekowschodniej medytacji są chrześcijańskie ruchy, takie jak centering prayer („modlitwa głębi” w polskich thumaczeniach) Thomasa Keatinga OCSO czy medytacja chrześcijańska Johna Maina OSB, które powstały w latach 70. i 80. pod wpływem kontaktów z nauczycielami medytacji z Azji. W przypadku centering prayer znaczące wydają się wpływy zen, a medytacja chrześcijańska Johna Maina zainspirowana została medytacją mantryczną, której nauczył się on od hinduskiego mnicha (swamiego) podczas pobytu w Malezji. Obie szkoły medytacji 
chrześcijańskiej szukają korzeni swojej niedyskursywnej praktyki w zapomnianym dziedzictwie tradycji chrześcijańskiej, zwłaszcza u ojców pustyni oraz w czternastowiecznym angielskim traktacie Obłok niewiedzy.

Co ciekawe jednak, praktyki te mają charakter niedyskursywny i stronią od filozofii, która przedstawiana jest jako bezpłodne ,intelektualizowanie". Problematyczny wydaje się również brak pogłębionej wiedzy na temat tradycji filozofii chrześcijańskiej antyku i średniowiecza (zwłaszcza neoplatońskiej) oraz ćwiczeń duchowych, które ona wypracowała, co powoduje, że nauczyciele tych metod sięgają po doktryny buddyjskie czy hinduistyczne, w niektórych przypadkach wychodząc poza obręb ortodoksji chrześcijańskiej. Nierzadko towarzyszy temu wizja cywilizacji zachodniej jako pozbawionej wymiaru duchowego czy mistycznego, skupionej na świecie zewnętrznym, życiu aktywnym i wąsko pojętym rozumie, oraz idealizacja tradycji Dalekiego Wschodu. Widać tu niekiedy swoisty kompleks niższości wobec tej ostatniej tradycji, która nawet przez chrześcijan postrzegana jest jako dysponująca doświadczeniem duchowym oraz metodami medytacji lepiej opracowanymi i skuteczniejszymi niż chrześcijaństwo ${ }^{1}$. Zwłaszcza w dawniejszych książkach pojawiały się motywy „ożywienia” martwej duchowo tradycji zachodniej witalnym tchnieniem praktyk buddyjskich i hinduistycznych.

Pogłębioną, filozoficzną i teologiczną analizę wszystkich tych tendencji „podróży na Wschód” w XX-wiecznej duchowości chrześcijańskiej można znaleźć w książkach neotomistycznego, amerykańskiego teologa Jamesa Arraja (zwłaszcza Christianity in the Crucible of East-West Dialogue i Critical Questions in Christian Contemplative Practice) $)^{2}$. W Polsce ukazała się na ten temat kilka lat temu książka Andrzeja Siemieniewskiego i Mirosława Kiwka Chrześcijańska medytacja monologiczna.

W niniejszym artykule zestawię ze sobą koncepcję samopoznania umysłu oraz metody medytacji tybetańskich szkół mahamudry i dzogczen, rozwijanych współcześnie przez nauczycieli medytacji na Zachodzie, z poglądami Grzegorza z Nyssy i Augustyna z Hippony na temat samopoznania i z filozoficznymi ćwiczeniami duchowymi, które można znaleźć w ich tekstach. Metodologicznie, zestawienie takie wydaje się problematyczne, gdyż teksty starożytne, powstałe w zupełnie innym kontekście, porównuję ze współczesnymi komentarzami nauczycieli medytacji do ezoterycznych tekstów powstałych w XVI i XIX wieku w Tybecie. Niemniej jednak tradycja antycznych, filozoficznych ćwiczeń duchowych jest współcześnie rozwijana, głównie za sprawą

${ }^{1}$ A. Siemieniewski, M. Kiwek, Chrześcijańska medytacja monologiczna: źródła i aktualne pytania, Wrocław 2013.

2 Obie książki dostępne są w formie elektronicznej: Christianity in the Crucible... (Cheloquin 2001) https://www.innerexplorations.com/catew/christia.html; Critical Questions... (Cheloquin 2007) https://www.innerexplorations.com/catchspmys/Critical.html. 
prac Pierre'a Hadota ${ }^{3}$. Obok nurtu naukowych badań nad tą tradycją pojawia się również nurt praktycznego nauczania i życia zgodnie $\mathrm{z}$ antycznymi szkołami filozoficznymi, zwłaszcza stoicką. Interesujące wydaje się więc, że tradycja filozoficznych ćwiczeń powraca do współczesnej kultury zachodniej poza chrześcijańskim kontekstem, podczas gdy w obrębie samego chrześcijaństwa rozwijają się praktyki niedyskursywne, stroniące od filozofii.

W poniższych rozważaniach wskażę, że u dwóch wspomnianych chrześcijańskich platoników, działających w IV i V wieku naszej ery, filozoficzna medytacja prowadząca do bezpośredniego oglądu natury umysłu, która ani nie jest metodą niedyskursywną i bezpojęciową, ani nie jest „,intelektualizowaniem", które nie prowadzi do żadnej duchowej przemiany, wydaje się w pełni rozwiniętą metodą duchową, zarazem filozoficzną i chrześcijańską. Zestawiając ją z metodami buddyjskimi, zwrócę uwagę na podobieństwa i różnice, zwłaszcza w filozoficznym kontekście tych praktyk duchowych.

\section{Samopoznanie umysłu w tybetańskich tradycjach mahamudry i dzogczen}

Buddyzm to tradycja zróżnicowana i ewoluująca przez wieki. Zwykle dzieli się ją na trzy „pojazdy” czy „wozy”: hinajanę lub therawadę (głównie Indochiny), mahajanę (Chiny, Japonia, Korea) oraz wadżrajanę (buddyzm tybetański). Chcę się przyjrzeć temu ostatniemu, w obrębie którego obecne są bardzo różne elementy, takie jak choćby wpływy tantry czy lokalnej tradycji bon. Dwie szkoły medytacji tybetańskiego buddyzmu, do których się odniosę, mahamudra i dzogczen, tym się wyróżniają, że ich celem jest bezpośredni wgląd w naturę umysłu osiągany za pomocą ćwiczeń introspekcyjnych, czyli badania własnego umysłu, które praktykowane są przy pomocy udzielającego wskazówek nauczyciela.

Odwołam się do dwóch komentarzy współcześnie działających nauczycieli medytacji do wcześniejszych tekstów duchowych, które mają charakter ezoteryczny i poetycki, toteż ich zrozumienie wymaga - w założeniu - właśnie komentarza kogoś, kto sam zrealizował duchowy ideał, o którym mówią. Jako przykład z nurtu mahamudry wybrałem komentarz Khenchena Thrangu

3 P. Hadot, Czym jest filozofia starożytna?, Kęty 2000; tegoż, Filozofia jako ćwiczenie duchowe, Kęty 2003; tegoż, Twierdza wewnętrzna: wprowadzenie do "Rozmyślań» Marka Aureliusza, Kęty 2004. Na temat ćwiczeń duchowych w języku polskim zob. również Therapeia, askesis, meditatio : praktyczny wymiar filozofii w starożytności i średniowieczu, red. K. Łapiński, R. Pawlik, R. Tichy, Warszawa 2017; K. Łapiński, Ananeou seauton: «Rozmyślania» Marka Aureliusza w kontekście grecko-rzymskiej praktyki filozoficznej, Warszawa 2018; M. Stróżyński, Filozofia jako terapia w pismach Marka Aureliusza, Plotyna i Augustyna, Poznań 2014. 
Rinpocze do tekstu Wskazywanie na dharmakaje autorstwa Wangchuka Dordże, dziewiątego karmapy (czyli zwierzchnika tybetańskiej szkoły Kagyu), żyjącego w drugiej połowie XVI wieku ${ }^{4}$. Nauczyciel w tym przypadku jest Tybetańczykiem, wychowanym i wykształconym w tradycji nieeuropejskiej, a jego metoda wykładu jest zasadniczo wolna od sięgania po elementy kultury zachodniej, w tym należącej do niej filozofii i religii.

Warto wspomnieć, że zarówno w mahamudrze, jak i dzogczen, należy spełnić pewne warunki wstępne, zanim przystąpi się do ćwiczenia wglądu we własny umysł, który stanowi istotę tych metod medytacji. Zwykle należy do nich zapoznanie się z poglądami metafizycznymi i epistemologicznymi, które stanowią kontekst praktyki. Często droga duchowa zaczyna się od ćwiczeń angażujących ciało, ćwiczeń wyobraźni i koncentracji, a bezpośrednie badanie natury umysłu stanowi kulminacyjny punkt. Zasadnicze jest opanowanie typu medytacji, który określa się w sanskrycie śamatha (tybetańskie: szine), czyli umiejętności utrzymywania nieprzerwanej koncentracji umysłu na dowolnie wybranym obiekcie. Buddyzm wychodzi od powszechnego doświadczenia, że nasza wola nie panuje nad umysłem; choć możemy sprawować nad nim pewną kontrolę, większość jego codziennej aktywności, w sensie tworzenia mentalnych obrazów i mowy wewnętrznej, odbywa się poza naszą kontrolą lub nawet wbrew niej, jeśli próbujemy na to wpłynąć. Dlatego niemożliwe jest wpatrywanie się w umysł, jeśli rozproszenia są zbyt duże. Umiejętnością wstępną jest zatem zdolność skupienia, którą ćwiczy się przez koncentrację na wybranym obiekcie - oddechu, płomieniu świecy, kwiecie itd. Dopiero opanowanie śamathy umożliwia praktykowanie drugiego typu medytacji, tzw. medytacji wglądu, czyli vipaśyany (tyb. laktong).

Thrangu Rinpocze w swoim komentarzu przedstawia doświadczenie samopoznania w kilku kontekstach - najpierw w stanie wewnętrznego spokoju, który uzyskujemy przez praktykę śamathy, a następnie w stanie pojawiania się myśli oraz $\mathrm{w}$ powiązaniu $\mathrm{z}$ doświadczeniem ciała i postrzeżeń zmysłowych. Najłatwiej jednak zobaczyć naturę umysłu w stanie wyciszenia i koncentracji, osiąganych poprzez śamathę. Wówczas adept jest w stanie doświadczyć paradoksalnego w swej naturze widzenia własnego umysłu:

Kiedy będziesz spoglądać na swój umysł, czy zobaczysz jakąś rzecz? [...] Nie, nie ma tam niczego takiego. Ponieważ nie ma tam żadnej rzeczy, którą moglibyśmy nazwać umysłem, Budda mówił o pustce czy braku jaźni. [...] Chodzi o to, że nieważne, jak dużo będziesz patrzył w swój umysł i nieważne, co spodziewasz się tam znaleźć, nie znajdziesz tam żadnej rzeczy. I nie znajdziesz nie dlatego, że nie wiesz, jak patrzeć na umysł, ani dlatego, że nie patrzysz z wystarczającym

${ }^{4} \mathrm{~K}$. Thrangu Rinpocze, Pointing Out the Dharmakaya. Teachings On the Ninth Karmapa's Text, New York 2003. 
wysiłkiem. Jest tak dlatego, że taka jest rzeczywistość. Nie ma żadnej rzeczy, żadnego substancjalnego istnienia w umyśle. To dlatego Trzeci Karmapa powiedział: „Umysł nie istnieje i nie zobaczył go żaden ze Zwycięskich”.

Thrangu opisuje zatem doświadczenie, w którym samopoznanie wydaje się nie osiągać żadnych skutków, ponieważ natura umysłu w ogóle nie jest przedmiotem wewnętrznego doświadczenia. Dodaje on jednak:

Nie ma nic do oglądania, kiedy patrzysz na umysł, ale, z drugiej strony, nie ma tam też absolutnej nieobecności czegokolwiek. Normalnie, kiedy mówimy o pustce, tworzymy pojęcie absolutnej nicości, absolutnego nieistnienia, jak w przypadku rogów królika albo pustej przestrzeni. Ale pustka, która jest naturą umysłu, nie na tym polega. To nie jest absolutna nicość. Na przykład, gdy patrzysz na umysł w kontekście praktyki śamathy, nie widzisz żadnego koloru, kształtu ani żadnej substancjalnej cechy. Ale nie jest to odkrycie absolutnej nicości, bo ta pustka, która jest naturą umysłu, nie jest pozbawiona czucia. Jest ona zarazem poznaniem i zdolnością poznawania, ponieważ umysł jest w istocie rzeczy tym, co może i co poznaje doświadczenie ${ }^{6}$.

Doświadczenie medytacyjne ujawnia, że umysł nie jest rzeczą, nie ma koloru, kształtu ani żadnych innych cech, które kojarzymy z substancją, ale równocześnie - że umysł poznaje albo raczej - że jest samą aktywnością poznawania. Ten pierwszy aspekt mahamudra nazywa za tradycją filozofii szkoły Madhyamaki, reprezentowanej między innymi przez Nagardżunę (150-250 n.e.), ,pustką”, a tę drugą nazywa „świetlistością” lub „poznawczą świetlistością". Thrangu podkreśla, że nie należy sądzić, iż skoro natura umysłu jest świetlista, to widzi się jakieś zmysłowe światło, kiedy się na nią patrzy. Chodzi o to, że umysł ma dwie cechy - niebycie „czymś” oraz zdolność poznawania, które są w nim jednym.

Mahamudra przypisuje więc umysłowi zdolność samopoznania czy samoświadomości (self-awareness) i przy tej okazji Thrangu odwołuje się do tradycji buddyjskiej, a konkretnie do filozofii madhyamaki, w której sformułowano doktrynę pustki. Madhyamaka bowiem zaprzecza istnieniu samoświadomości, twierdząc, że jest absolutnie niemożliwe, żeby umysł był świadomy siebie. Thrangu zwraca uwagę, że rozumienie samoświadomości w madhyamace jest inne niż w mahamudrze - w tradycyjnej doktrynie pustki mówi się, że umysł nie może widzieć siebie w tym sensie, że nie może widzieć siebie jako substancji, jako rzeczy, która ma określone cechy. W mahamudrze jednak samoświadomość nie oznacza nic innego jak doświadczenie tego, że umysł jest

\footnotetext{
5 Tamże, s. 70.

6 Tamże.
} 
pusty i świetlisty, czyli że zarazem nie widać go, gdy się na niego patrzy, ale on jest widzeniem: „mamy tu na myśli, że umysł jest świadom swojej natury, którą jest pustka"’.

Thrangu do opisania tego paradoksalnego doświadczenia używa metafory oka, mówiąc, że kiedy w mahamudrze umysł widzi sam siebie, nie chodzi tu o sytuację, w której oko zobaczyłoby samo siebie, co jest niemożliwe - chyba że w zwierciadle. Umysł jest zupełnie innej natury niż obiekty zmysłowe, toteż jego widzenie samego siebie oznacza, że „będąc świadomością, doświadcza swojej własnej świadomości. W istocie, nie jest to wcale trudne do osiągnięcia, bo umysł nie szuka czegoś, co by było daleko. To jest tutaj"8.

Nie trzeba więc nic dodawać ani nic dodatkowego uzyskiwać, a jedynie zobaczyć coś, co już się dzieje i jest w pełni dostępne. Thrangu przytacza tutaj obraz pochodzący z poematu Rozpoznawanie matki, autorstwa osiemnastowiecznego mistrza Changkya Rolpe Dordże. W tym poemacie opisane jest dziecko, które siedzi zadowolone na kolanach matki i czuje się bezpiecznie, do momentu, w którym przyjdzie mu na myśl, że nie widzi matki. Zaczyna jej szukać, patrzy w górę, w dół, w lewo i w prawo, nigdzie jej nie widząc. Zaczyna więc płakać i żalić się: „Gdzie jest matka? Zgubiłem ją, nie mogę jej znaleźć!” W pewnym momencie do dziecka podchodzi starszy brat, który mówi do niego: „Matka jest tutaj - przecież siedzisz na jej kolanach!” I w tym momencie dziecko się uspokaja. Umysłu w jego istocie nie można zobaczyć, bo jest on niejako ,za nami” - jak matka w tej metaforze - a zarazem jest cały czas obecny i ujawnia się przez swoją świetlistość, toteż możemy poczuć się w nim bezpiecznie i - jak dziecko wtulone w matkę - czuć obecność, której nie możemy zobaczyć. Thrangu komentuje: „W ten sam sposób, choć natura naszego umysłu czy pustki jest z nami cały czas, zwykle szukamy jej nie tam, gdzie trzeba; szukamy jej gdzieś poza nami, gdzieś daleko"9. Problem w poznaniu własnego umysłu polega nie na jego niedostępności, ale na naszym nawykowym zainteresowaniu innymi rzeczami, na orientacji „na zewnątrz” albo „ku obiektom”.

Drugim tekstem, którym chcę się krótko zająć, jest komentarz Jamesa Lowa do dziewiętnastowiecznego tekstu Nudana Dordże Zwierciadło jasnego znaczenia ${ }^{10}$. W tym przypadku mamy do czynienia z nauczycielem medytacji urodzonym i wychowanym na Zachodzie, znającym zachodnią tradycję filozoficzną i niekiedy odwołującym się do kontekstu kultury zachodniej podczas nauczania. Niemniej jednak, odwołania do filozofii antycznej i średniowiecznej oraz do chrześcijaństwa są zasadniczo nieobecne.

7 Tamże, s. 103.

8 Tamże, s. 104.

9 Tamże, s. 102.

10 J. Low, Być tu i teraz. "Zwierciadło jasnego znaczenia», terma dzogczen Nudana Dordże $z$ komentarzem Jamesa Low, tłum. J. Janiszewska-Rain, Kraków 2005. 
W pierwszej strofie poematu Nudana Dordże pojawia się metafora, podobna do tej, która użyta jest w komentarzu Thrangu Rinpocze - metafora widzenia własnej twarzy (u Thrangu jest to widzenie własnego oka). Tybetański autor powiada: „stosując tę tajemną instrukcję, można zobaczyć własną twarz, własną obecność”"11, a James Low komentuje: „Jeśli chcecie ujrzeć własną twarz, musicie spojrzeć w zwierciadło, i wtedy widzicie siebie jako odbicie, w którym prawa strona zamieniła się z lewą. To, co widzicie, jest więc czymś innym niż wy sami" ${ }^{2}$. Umysł nie może zatem zobaczyć siebie jako obiektu, jako rzeczy, a jeśli zobaczy, to nie będzie to on w swojej naturze, ale jakaś reprezentacja i odbicie.

Doświadczenie własnego umysłu jest zaś czymś innym, czyli doświadczeniem niewidzenia niczego konkretnego:

Coś tam jest. Nie musicie wiedzieć, czym to coś jest, ale jest. Pojawia się także odczucie zmiany mające powiązanie z energią. Można ją poczuć w chwili, gdy się zmienia. Być może trudno dokładnie określić, co to jest. Ta mglistość, niejasność, trudność w uchwyceniu naturalnej obecności jako specyficznej rzeczy jest jakością pustki ${ }^{13}$.

Pustka jest zatem zdefiniowana jako „trudność w uchwyceniu” umysłu, a zarazem nie oznacza ona nicości w sensie nieobecności istnienia. Coś jest, ale nie możemy poznać, co to jest. Low zwraca też uwagę na inny element, czyli na rolę nawyku, która oślepia nas w poszukiwaniach natury umysłu:

Przywykliśmy obserwować rzeczy. Jeśli będziemy obserwować siebie w taki sam sposób, w jaki obserwujemy rzeczy, bez wątpienia sami zaprezentujemy się swojemu ,ja” jako rzecz, ponieważ to właśnie robiliśmy od samego początku samsary. Bo właśnie na tym polega samsara ${ }^{14}$.

Samsara, nieustanne koło wcieleń i cierpienia, ujęta jest więc tutaj niejako intrapsychicznie czy mikrokosmicznie, jako nieustannie się powtarzająca próba zobaczenia umysłu jako „,zegoś”, co właśnie jest oddaleniem się od prawdziwego poznania. Dla medytacji spoglądania w umysł tekst Nudana Dordże zaleca pomocnicze pytania, takie jak: „Skąd pochodzi, gdzie przebywa i dokąd idzie? Jaki ma kształt i kolor?"'15. James Low dodaje zaś inne wskazówki:

\footnotetext{
11 Tamże, s. 19.

12 Tamże, s. 23.

13 Tamże, s. 20.

14 Tamże, s. 35.

15 Tamże, s. 75.
} 
Ktoś tu jest, czyli jest jakiś rodzaj obecności. Gdzie jest ta obecność? Czy ona się na czymś opiera? Czy cokolwiek znajduje się poza nią? Czy jest coś, co ją podtrzymuje? Czy jest w jakikolwiek sposób umiejscowiona? Nie robimy tej praktyki zbyt długo, ponieważ potrzeba do niej wyostrzonego umysłu ${ }^{16}$.

Jest to ćwiczenie poszukiwania swojego umysłu, umiejscowione w kontekście poglądu, że nic się nie znajdzie, bo umysł nie jest rzeczą. To, że jest pusty, czy sama jego pustka, wyjaśnione zostaje jako: „[umysł] nie jest obecny jako coś, co możesz postrzegać tak, jak obiekt" ${ }^{\prime 17}$. Inaczej ujmuje to czternasta strofa komentowanego poematu: „Tego, co zwiemy umysłem, nie sposób określić jako to czy tamto. Nie jest jakąś rzeczą i nie ma definiujących go cech. Jeśli go szukasz, nie możesz go znaleźć, ponieważ od samego początku jest pusty"18. Niemniej jednak, James Low uzupełnia aspekt pustki tym, co w mahamudrze nazywa się świetlistością umysłu: „Tym, co mamy, jest ta obecność, przytomność, bo przecież tu jesteśmy, coś się dzieje, wszyscy zdajemy sobie sprawę z bycia tutaj"19.

W tym typie medytacji mamy do czynienia z ciągłym i konsekwentnym rozpoznawaniem kolejnych pojawiających się w umyśle zjawisk jako nie-umysłu, jako obiektów, które nie mogą być podmiotem świadomości, a jedynie jej przedmiotem. To prowadzi w końcu do quasi-pozytywnego poznania natury umysłu. Okazuje się on przede wszystkim świetlisty, czyli poznający, ale medytacja ujawnia również inne jego cechy. Jak powiada w 14. strofie Nudan Dordże - „Pusty, niewysłowiony, nie dotknięty przez narodziny, śmierć, przychodzenie i odchodzenie" ${ }^{20}$. Można powiedzieć, że wgląd w naturę umysłu przekonuje medytującego, że natura ta nie dzieli absolutnie żadnych jakości z przedmiotami naszego poznania, czyli z bytami zmysłowymi: nie przemija, nie umiera, nie rodzi się, nie powstaje na naszych oczach, nie znika itd. $\mathrm{Na}$ tej podstawie dochodzimy do wniosku, że jest wieczny, niezniszczalny, niezmienny itd. W buddyzmie jednak umysł nie jest żadną substancja, która miałaby atrybuty wieczności czy niezmienności - jest pozbawionym substancji poznawaniem czy samą aktywnością poznawania, odsłoniętą w naszym doświadczeniu. Ponieważ to doświadczenie nie daje nam dostępu do żadnej istoty, sama substancjalność umysłu zostaje zanegowana.

W buddyzmie tybetańskim zakłada się, że umysł jest jeden, a świat jest jego przejawianiem się w postaci obiektów, a indywidualność ma charakter wyłącznie zjawiskowy, to znaczy jest złożeniem ciała, wspomnień, myśli,

\footnotetext{
16 Tamże, s. 84.

17 Tamże, s. 87.

18 Tamże, s. 85.

19 Tamże, s. 88.

20 Tamże, s. 85.
} 
emocji, pragnień, nawyków, niezakorzenionym w żadnej odrębnej metafizycznie substancji. James Low w swoim komentarzu zwraca jednak uwagę na pewną kwestię:

„Twój umysł jest korzeniem wszystkich zjawisk”. To bardzo mocne stwierdzenie! Oznacza najwyraźniej, że wszystko, co istnieje na świecie, ma swój korzeń $\mathrm{w}$ twoim własnym umyśle. Przebywamy zatem w tym pomieszczeniu, każdy z nas czyta to stwierdzenie i każdy dochodzi do wniosku: „Mój umysł jest korzeniem wszystkich zjawisk". Sprawy się jednak komplikują, bo każdy z nas jest jednocześnie zjawiskiem dla innych ${ }^{21}$.

Low dopuszcza hipotezę, której nie spotyka się w zasadzie u współczesnych nauczycieli medytacji buddyjskiej, czyli że umysłów - nie w sensie zjawiskowym, ale w sensie podstawy zjawisk - może być wiele: „Czy istnieje jeden umysł $\mathrm{z}$ wieloma różnymi wejściami, czy raczej jest wiele oddzielnych, całkowicie oświeconych umysłów, które po prostu świetnie tańczą?"22. Bardzo znaczący jest jednak następujący po tym komentarz: „To bardzo ciekawe pytanie i jednocześnie kompletny nonsens". Nonsens, ponieważ pojęciowe, dyskursywne myślenie szukające rozstrzygnięcia tego problemu jest tylko nominalistyczną grą, operowaniem słowami, które nie prowadzą nas do prawdy ani do wyzwolenia od cierpienia. Low nie zaprzecza metafizycznej tezie o istnieniu wielu umysłów, ale uznaje ją za nieistotną. Buddyzm jest skrajnie pragmatyczny i terapeutyczny, toteż pojęciowe poszukiwanie prawdy ma tylko wartość relatywną, podczas gdy absolutną wartość ma doświadczenie wglądu w naturę umysłu, które uwalnia i przemienia. W jakimś zatem sensie dzogczen w ogóle nie rozstrzyga pytania o to, czy umysł jest jeden, czy jest ich wiele; zostaje przy doświadczeniu, w którym dla każdego istnieje jeden, absolutny umysł.

Jeszcze bardziej problematyczna jest kwestia Boga i relacji wielości umysłów do Umysłu nieskończonego i absolutnego. W buddyzmie ona się w ogóle nie pojawia. Dlatego nie znajdziemy w mahamudrze i dzogczen ani śladu chrześcijańskiej spekulacji filozoficznej na temat relacji ludzkiego umysłu do Boga jako Umysłu absolutnego. Również w tym obszarze ujawnia się absolutne traktowanie osobistego doświadczenia umysłu i niechęć do wyjścia poza pole bezpośredniego wglądu, które można reprodukować dzięki wytrwale praktykowanej medytacji. Nie twierdzę, że w buddyzmie nie ma filozofii, myślenia analitycznego i pojęciowego, ponieważ jest go bardzo wiele - istnieje logika, metafizyka i epistemologia, rozwijająca się w obrębie różnych

\footnotetext{
${ }^{21}$ Tamże, s. 76.

22 Tamże.
} 
szkół. Natomiast status tej filozofii wydaje się fundamentalnie inny niż w tradycji zachodniej ${ }^{23}$.

\section{Grzegorz z Nyssy: umysł niepoznawalny}

Przekonanie o niemożliwości poznania przez ludzki umysł (nous) jego własnej istoty (ousia) w bezpośredniej intuicji, ta swoista ,,apofatyczna antropologia”, obecna jest w całej twórczości Grzegorza z Nyssy². W niniejszym tekście przedstawię koncepcję niemożności intuicyjnego samopoznania na przykładzie mniej znanego i rzadziej komentowanego urywku z dialogu O duszy i zmartwychwstaniu, ze względu na jego bardzo praktyczny i doświadczeniowy charakter, zakorzeniony wyraźnie w neoplatońskich ćwiczeniach duchowych, w których wgląd w naturę podmiotu był zasadniczy ${ }^{25}$.

Uwagę uczonych w większym stopniu przykuwały inne, bardziej doktrynalne teksty Grzegorza, w których motyw niepoznawalności umysłu też się pojawia - dobrym przykładem tego typu perspektywy jest pierwszy rozdział klasycznej monografii Jeana Danielou poświęconej Nysseńczykowi, w którym zajmuje się on właśnie problemem samopoznania i jego relacji do poznania Boga $^{26}$. Również inni autorzy piszący o samopoznaniu u Grzegorza pomijają

${ }^{23}$ Myślę, że dobrze to ilustruje krótka wymiana, którą odbyłem z Jamesem Lowem podczas jednego z odosobnień dzogczen, w których przed laty uczestniczyłem. Kiedy zadałem mu pytanie o Boga, Low odpowiedział, że skoro on nigdy nie doświadczył istnienia „Taty w niebie”, nie ma podstaw do tego, by przyjmować Jego istnienie. O specyfice buddyjskiego stosunku do spekulacji metafizycznej pisze James Arraj w piątym rozdziale książki God, zen, and the intuition of being, http://www.innerexplorations.com/catew/3.html [dostęp: 22.06.2020]. Szerzej rozwija swoją koncepcję napięcia między elementem subiektywnym i obiektywnym w metafizyce w książce: Mysticism, metaphysics and Maritain, https://www.innerexplorations.com/catchmeta/1.html [dostęp: 22.06.2020].

${ }^{24} \mathrm{O}$,apofatycznej antropologii” pisze Deirdre Carabine, zwracając uwagę na sprzeczność tej koncepcji z filozoficzną tradycją, zarówno pogańską, sokratyczną, jak i chrześcijańską (Augustyn). (D. Carabine, Gregory of Nyssa on the Incomprehensibility of God, w: The relationship between Neoplatonism and Christianity, red. T. Finan, V. Twomey, Dublin 1992, s. 82).

${ }_{25}$ Aktualną bibliografię dotyczącą zarówno pogańskich, jak i chrześcijańskich, neoplatońskich ćwiczeń duchowych można znaleźć w mojej książce Filozofia jako terapia w pismach Marka Aureliusza, Plotyna i Augustyna, Poznań 2014 oraz w artykule Spiritual Exercise in the Proem to Augustine's «Confessions», „Augustinian Studies" 49, 2 (2018), s. 221-245.

${ }^{26}$ Zob. J. Daniélou, Platonisme et théologie mystique. Doctrine spirituelle de Saint Grégoire de Nysse, Aubier 1944, s. 41-45. Daniélou korzysta głównie z De vita Moysis i Commentarius in Canticum canticorum, choć wspomina o De anima et resurrection ze względu na obecną tam metaforę zwierciadła duszy. Co ciekawe, inaczej niż Carabine, Daniélou nie podkreśla sprzeczności z tradycją, ale zwraca uwagę na podobieństwa w myśli Grzegorza i Augustyna oraz Plotyna, zwłaszcza jeśli chodzi o ogólną teorię powrotu duszy do Boga, oczyszczenia i zjednoczenia. 
dialog $O$ duszy $i$ zmartwychwstaniu ${ }^{27}$. Z kolei badacze komentujący dialog $O$ duszy, zwykle nie odnoszą się do tej niedługiej sekcji, w której pojawia się temat samopoznania, zajmując się bardziej kwestiami doktrynalnymi związanymi z relacją duszy i ciała, nieśmiertelnością duszy i filozoficzną interpretacją zmartwychwstania ${ }^{28}$.

W dialogu siostra Grzegorza i Bazylego Wielkiego, Makryna, obsadzona jest w roli mędrca i nauczyciela (jest to aluzja do Platońskiej Diotymy z Uczty), podczas gdy Nysseńczyk stylizuje się na niezbyt rozgarniętego rozmówcę. W pewnym momencie Makryna zaczyna mówić o poznaniu umysłu w sposób bardzo praktyczny:

Trzeba zaś zbadać, co należy mniemać o umyśle co do jego istoty (ousia). To tego bowiem właśnie dotyczy nasz wywód, skoro nie podlega wątpliwości ukazujące się nam działanie (energeia) umysłu. Ten zatem, kto chce we właściwy sposób poznać to, czym umysł jest, odkryje to, poznając, że nie jest on czymś, co może uchwycić doświadczenie zmysłowe - ani kolorem, ani kształtem, ani twardością, ani ciężarem, ani ilością, ani rozciągłością w trzech wymiarach, ani położeniem w przestrzeni, ani w ogóle niczym z tego, co można uchwycić w materii, jeśli istnieją w niej jeszcze inne jakieś cechy.

Ja na to, przerywając jej w pół słowa:

- Nie wiem - powiedziałem - jak to możliwe, że po usunięciu tych wszystkich rzeczy z naszego myślenia nie zniknie nam wraz z nimi i to, co badamy! Nie można bowiem dostrzec, wedle mojego rozumienia, co miałoby być przedmiotem aktywności poznawczej poza tymi rzeczami. Wszędzie bowiem, gdy badamy naszym analizującym rozumem rzeczy istniejące, próbujemy wymacać

${ }^{27} \mathrm{~Np}$. Carabine skupia się głównie na De hominis opificio (Gregory of Nyssa on the Incomprehensibility, s. 88-91). Martin Laird interpretuje w ogólniejszym kontekście mistycyzmu Grzegorza De virginitate, De vita Moysis oraz Commentarius in Canticum canticorum. Jego ciekawe interpretacje „nieuchwytności” (ungraspability) Boga nie zostają odniesione do samopoznania umysłu (M. Laird, Gregory of Nyssa and the Grasp of Faith. Union, Knowledge, and Divine Presence, New York 2004, s. 34, 108-111). David Hart pisze ciekawie o metaforze zwierciadła u Grzegorza, o jego „,szklistej esencji” oraz „zmienności i plastyczności” umysłu, ale pomija dia$\log O$ duszy. (D.B. Hart, The Mirror of the Infinite: Gregory of Nyssa on the "vestigia Trinitatis», w: Re-thinking Gregory of Nyssa, red. S. Coakley, s. 117-121).

${ }^{28}$ G.B. Ladner, The Philosophical Anthropology of Saint Gregory of Nyssa, „Dumbarton Oaks Papers" 12 (1958), s. 59-94; C.P. Roth, Platonic and Pauline Elements in the Ascent of the Soul in Gregory of Nyssa's «Dialogue on the Soul and Resurrection», „Vigiliae Christianae” 46, No. 1 (Mar., 1992), s. 20-30; E. Peroli, Gregory of Nyssa and the Neoplatonic Doctrine of the Soul, „Vigiliae Christianae” 51, No. 2 (May, 1997), s. 117-139; M.R. Barnes, Divine unity and the divided self: Gregory of Nyssa'a trinitarian theology in its psychological context, w: Re-thinking Gregory of Nyssa, red. S. Coakley, Blackwell-Oxford 2003, s. 48-50; G.C. Stead, Ontology and Terminology in Gregory of Nyssa, w: Gregor von Nyssa und die Philosophie: Zweites Internationales Kolloquium Gregor von Nyssa, red. H. Doerrie, M. Altenburger, U. Schramm, Leiden 1976, s. 48; R. Williams, Macrina's Deathbed Revisited: Gregory of Nyssa on Mind and Passion, w: Christian Faith and Greek Philosophy in Late Anitquity, red. L. Wickham and C. Bammel, Leiden 1993, s. 227-246. 
to, czego poszukujemy, jak jacyś ślepcy, których ktoś prowadzi za rękę wzdłuż ściany ku drzwiom, i zawsze dotykamy jednej z tych wspomnianych cech - albo kolor znajdując, albo kształt, albo ilość, albo coś innego z tych rzeczy dopiero co przez ciebie wyliczonych. Kiedy zaś mówi się, że coś ma być niczym z tych rzeczy, z powodu ograniczenia naszej duszy zmierzamy do poglądu, że nie jest to w ogóle czymś.

A ona $\mathrm{z}$ oburzeniem mi przerwała w pół słowa:

- A co to w ogóle za niedorzeczność! - powiedziała - na jakie to dno prowadzi nas tak skarlała i przyziemna opinia o rzeczywistości! Jeśli bowiem usunie się z rzeczywistości wszystko, czego nie można poznać w doświadczeniu zmysłowym, czy nie uzna się, że w ogóle nie istnieje również i ta Moc ponad wszystkim stojąca i całą rzeczywistość ogarniająca; ktoś dowiedziawszy się, że skoro jest Ona czymś niecielesnym i - dla natury naszego widzenia - pozbawionym formy, pomyśli na mocy tego samego rozumowania, że Ona w ogóle nie istnieje. Jeśli zaś fakt, iż nie jest Ona niczym takim, nie staje się ograniczeniem jej istnienia, to jak ludzki umysł miałby ulec zniszczeniu, jakby wyżęty z wszelkiej realności, poprzez usunięcie tych cielesnych właściwości? ${ }^{29}$

Jednym z kluczowych słów w tym urywku wydaje się słowo katalambano, które dosłownie znaczy 'chwytać' czy 'łapać', a metaforycznie - 'pojmować' i 'poznawać'. Makryna twierdzi, że umysł dla samego siebie jest nieuchwytny w bezpośrednim doświadczeniu, to znaczy, że gdy zwracamy wzrok wewnętrzny na nasz umysł i próbujemy doświadczyć jego istoty, nie znajdujemy tam nic $\mathrm{z}$ tych zmysłowych jakości, które odnajdujemy w rzeczach materialnych. Grzegorz bierze tu na siebie pozornie rolę niezbyt bystrego ucznia, który wysnuwa $\mathrm{z}$ tego konkluzję, że skoro szukając własnego umysłu, nie możemy go znaleźć i nie napotykamy w doświadczeniu wewnętrznym na nic, co by było jakimś kształtem, kolorem, rozciągłością itd., to równie dobrze można by pomyśleć, że nasz umysł jest niczym lub w ogóle nie istnieje.

Na pierwszy rzut oka wydaje się, że to doświadczenie nicości własnego umysłu nie jest pierwszym, co napotykamy w introspekcji, bo przecież coś się w nas cały czas dzieje. Niemniej jednak, Makryna wyraźnie mówi, że nie chodzi jej o energeia, czyli o działanie lub aktywność, którą umysł przejawia, gdyż ona jest dla nas poznawalna niewątpliwie. Możemy poznać akty poznania naszego umysłu i w związku z tym - umysł jako poznający, jeśli jednak szukamy leżącej pod tymi aktami istoty, ousia - wtedy nie widzimy nic. Grzegorz wysnuwa więc dość logiczną konkluzję z tego doświadczenia badania własnego umysłu, zawieszając na moment to, co jest konwencjonalną czy tradycyjną wiedzą o umyśle. Ponadto mówi on nie tyle, że umysłu nie ma, ile że

${ }^{29}$ De anima et resurrectione 24.14-26.5 (De anima et resurrectione, Gregorii Nysseni Opera, t. III, cz. III, red. A. Spira, Leiden 2014). Wszystkie cytaty w moim thumaczeniu. 
„umysł nie jest w ogóle czymś”. Jeśli bowiem przez „coś” rozumiemy to, co ma jakości zmysłowe (a nasze zanurzenie w tym, co materialne, powoduje, że nawykowo za „coś” uważamy właśnie jakości zmysłowe), umysł z pewnością nie jest czymś - czy to jednak oznacza, że jest niczym albo że w ogóle nie istnieje?

Praktyczny i bliski doświadczeniu sposób myślenia Grzegorza ujawnia się też w porównaniu, które stosuje dla tego typu medytacji. Mówi o ślepcach, którzy macają ręką po ścianie, żeby natrafić na drzwi - tak funkcjonuje ludzki umysł, w tym sensie, że nasze poznanie chce opierać się na czymś zmysłowo namacalnym, czyli obdarzonym cechami posiadanymi przez rzeczy materialne. W medytacji stajemy się więc jak ślepiec, który maca w swoim umyśle, szukając czegoś materialnego i zmysłowego, ale nie może niczego takiego tam znaleźć. Nie ma bowiem drzwi, które ślepcowi posuwającemu się wzdłuż ściany przynoszą w końcu ulgę: „znalazłem wyjście”. Jest to więc sytuacja dosłownie aporetyczna, czyli pozbawiona wyjścia i drzwi, które otwierałyby się na światło poznania czegoś. Jest to raczej wejście w ciemność poznania niczego konkretnego, niemniej jednak - jak porównanie Grzegorza sugeruje umysł mimo to istnieje, bo ktoś tu przecież maca w ciemnościach i posuwa się wzdłuż czegoś, gdy badamy naturę umysłu. O tym, że istniejemy, upewnia nas energeia, nasze działanie poznawcze, którego sama medytacja jest przejawem, ale o tym, czym jesteśmy, niczego nie możemy się dowiedzieć.

Warto nadmienić swoją drogą, że o podobnym doświadczeniu pisze też Plotyn i Grzegorz może tu do niego nawiązywać ${ }^{30}$. Autor Ennead pisze:

Tam więc [scil. na poziomie noetycznym], kiedy najpełniej poznajemy intelektualnie, wydaje się nam, że niczego nie spostrzegamy [agnoein], bo czekamy na doświadczenie zmysłowe, a świadomość zmysłowa mówi, że nic nie widzi. Nie zobaczyła bowiem i nigdy tego typu rzeczy nie zobaczy. Tym, co wówczas nie dowierza, jest właśnie świadomość zmysłowa, a ten, kto widzi, jest kimś innym, a gdyby i widzący nie dowierzał, nie dowierzałby wtedy w to, że on sam istnieje. Nie jest bowiem w stanie umieścić siebie poza sobą i patrzeć na siebie oczyma cielesnymi, jakby był czymś zmysłowym ${ }^{31}$.

Plotyn używa tutaj słowa agnoein, które może oznaczać „,nie spostrzegać, nie rozpoznawać, nie wiedzieć”, ale niesie ze sobą jeszcze potężniejsze konotacje pogrążenia się w stanie niewiedzy. W Odysei (20.15) np. użyte jest w odniesieniu do psa, który nie rozpoznaje swojego właściciela, i Plotyn

${ }^{30}$ Wpływ Plotyna na Grzegorza jest słabo udokumentowany w literaturze przedmiotu, ale trudno go wykluczać, zob. na ten temat: J.M. Rist, Plotinus and Christian philosophy, w: Cambridge Companion to Plotinus, red. L.P. Gerson, s. 399-400.

31 Enn. 5.8.11.33-40, Plotinus, Enneads, Cambridge-London 1966-1988. 
zapewne też o tym mówi tutaj, że umysł (nous) sam siebie nie rozpoznaje, choć wprost na siebie patrzy. Jednak twórcy neoplatonizmu bliżej z pewnością do tego urywka Uczty Platona, w którym Alkibiades mówi o Sokratesie, że tak jest wstrząśnięty (ekpeplektai) pięknem chłopców, iż „niczego nie jest świadomy i nic nie wie" (agnoei panta kai ouden oiden, 216d). Mamy tu więc aluzję do stanu dezorientacji i ekstatycznej utraty świadomości, która w kontekście Platońskiego erosa zawsze dotyczy pierwszych momentów oglądania inteligibilnego piękna.

U Plotyna nie znajdziemy „ciemności” ani „oślepienia”, gdyż bardzo konsekwentnie trzyma się tradycyjnej symboliki światła, natomiast bardzo wyraźnie mówi on o stanie niewiedzy i dezorientacji z nim związanej. Plotyn wyjaśnia to doświadczenie wpatrywania się we własny umysł poprzez odwołanie do swojej koncepcji poziomów świadomości i poziomów Ja. Jeśli nasze Ja utożsamia się ze świadomością zmysłową, wtedy czujemy dezorientację, że nic nie widzimy, patrząc w swój umysł, i pojawia się „niedowierzanie” czy „brak wiary/ufności" (apistoun) w to, że nasze doświadczenie ma jakąkolwiek wartość poznawczą. Jeśli jednak wzniesiemy się ponad poziom zmysłowy i utożsamimy się ze świadomością noetyczną, wtedy pojawi się w nas, obok widzenia własnego umysłu, również wiara (pistis) w to, że poznajemy coś nie tylko realnie istniejącego, ale bardziej realnego od bytów materialnych.

Plotyn nie ma wątpliwości, że tym, co widzimy, patrząc w swój umysł i czując, że nic nie widzimy, jesteśmy my sami, istota naszego umysłu i centrum naszego Ja, toteż twierdzenie, że niczego tam nie ma, oznaczać by musiało, że nas nie ma. W tej krótkiej antycypacji Kartezjańskiego cogito, Plotyn interpretuje to doświadczenie jako paradoksalny wgląd w umysł, w którym pewność jego istnienia łączy się z niewidzeniem niczego, co by miało jakiekolwiek zmysłowe jakości. Dodaje on na koniec, że niczego innego nie powinniśmy się spodziewać, ponieważ nie możemy zobaczyć swojego umysłu jako obiektu oddzielonego i rzutowanego poza umysł, tak jakby był czymś materialnym. Samopoznanie umysłu jest doświadczeniem, które nie ma analogii w sferze doświadczenia zmysłowego, które zawsze kieruje się na obiekt różny od postrzegającego Ja i ujmuje ten obiekt jako będący na zewnątrz Ja.

Innym miejscem Ennead, do którego warto w tym kontekście sięgnąć, jest trzeci rozdział traktatu 6.9, gdzie również jest mowa o dezorientacji i zamęcie podczas medytacji, ale dotyczy on nie tyle poznania samego umysłu, ile poznania Jedna ponad umysłem:

A im bardziej dusza zbliża się do tego, co bezforemne, tym bardziej braknie jej sił, by je objąć, gdyż ani nie ma ono żadnych granic, ani nie przypomina kształtu wyciśniętego przez jaką́s kunsztowną formę, i ześlizguje się ona w obawie, że niczego nie osiągnie. Męczy się zatem tymi wysiłkami i z ulgą zstępuje w dół, 
jakby odpadając od tego wszystkiego, aż w końcu zstąpi na poziom obiektów zmysłowych, spoczywając tam niby na jakimś twardym gruncie. To tak jak wzrok, zmęczony wypatrywaniem drobnych przedmiotów, chętnie spoczywa na dużych. (Enn. 6.9.3)

Jedno jest nie tylko niematerialne i niezmysłowe, ale nie ma w ogóle żadnej formy i w żadnym sensie nie może stać się obiektem poznania, nawet intelektualnego, toteż nie ma o nim żadnej wiedzy, ale można jego doświadczyć bezpośrednio za sprawą „obecności potężniejszej od wiedzy” (6.9.4). Niemniej jednak w mistyce Plotyna poznanie pozbawionego formy Jedna odbywa się przez poznanie pozbawionego formy Ja tego, który się do Jedna wznosi. Oznacza to, że stan dezorientacji i niewidzenia niczego podczas wpatrywania się w siebie musi ulec absolutnej intensyfikacji, aby nasza własna niepoznawalność i ,nicość” przeszła w doświadczenie niepoznawalności i ,nicości” samego Jedna.

Podczas tego procesu dusza, jak zwraca uwagę Plotyn, często męczy się i ,ześlizguje” w doświadczenie zmysłowe, ponieważ do niego jest przyzwyczajona i ono wydaje się jej pewnym gruntem, czymś realnym, konkretnym. Wspomina też o lęku czy obawie (co koresponduje $\mathrm{z}$,niedowierzaniem" z Enn. 5.8.11), że niczego nie osiągamy, skoro nic nie widzimy i nie napotykamy żadnego „,czegoś” w medytacji. Stan ten Plotyn rozwiewa pod koniec traktatu 6.9, gdy powiada: „natura duszy nie dotrze bowiem do całkowitego niebytu” i dodaje „nie dotrze do niczego innego, lecz do samej siebie, a w ten właśnie sposób nie będąc w niczym innym od siebie, nie znajdzie się w niczym, ale w samej sobie" (6.9.11.36-41). Tutaj Plotyn znowu podkreśla, że dotarcie do samego centrum umysłu jest doświadczeniem, które może się wydawać „niczym” z powodu braku obiektów, które byłyby „czymś” innym od samego umysłu, natomiast bez względu na to, że to właśnie pełne bycie umysłu sobą samym i oglądanie samego siebie w swojej najgłębszej istocie. Co więcej, dla Plotyna jest to brama do obecności Jedna, „obecności potężniejszej od wiedzy", ponieważ: ,jeśli ktoś widzi, że tym się stał, posiada wtedy siebie jako podobieństwo do tamtego [Jedna] i jeśli od siebie przejdzie do niego jak od obrazu do pierwowzoru, dojdzie do kresu podróży" (6.9.11.43-46). Centralną metaforą tego przejścia od samopoznania do poznania Jedna jest metafora obrazu i podobieństwa.

U Grzegorza, który wydaje się znać przytoczone przeze mnie teksty Plotyna, pojawiają się ciekawe modyfikacje, przede wszystkim odejście od jednoznacznej metaforyki światła i widzenia na rzecz ciemności, ślepoty i dotyku. Eksponuje on też moment niepewności, niewiary i dezorientacji, nie korzystając $\mathrm{z}$ tej formy argumentu cogito, co Plotyn. Makryna nie mówi przecież, że umysł istnieje, nawet gdy nie widzi siebie, bo żeby nie widzieć siebie, musi 
przecież być. Raczej, z oburzeniem przerywa ona rozmyślania Grzegorza, uznając za absurdalny pomysł, że umysł mógłby nie istnieć (być może argument cogito jest tutaj założony i domyślnie uznany za oczywisty?). Makryna nie podaje jednak dowodu na istnienie umysłu ani nie podejmuje dyskusji z tym, co powiedział Grzegorz. Mówi jedynie - co bardzo intrygujące - że równie dobrze można by zanegować istnienie Boga, który ma taką samą naturę jak umysł. Jego również nie można uchwycić, a jest przecież paradygmatem tego, co realne, prawdziwe, tego, co istnieje. Słychać tu znowu echo Plotyńskiej myśli, że to tylko przywiązanie do świadomości zmysłowej nie pozwala nam mieć pewności istnienia umysłu, który jest widziany w inny sposób.

Grzegorz dotyka również tego wątku obecnego u Plotyna, czyli przekonania, że to upadek duszy i jej zanurzenie w materii powodują, iż czuje się ona niewygodnie w medytacji samopoznania. Mówi bowiem o ograniczeniu duszy (dosłownie: mikropsychii, małoduszności) i o nastawieniu „skarlałym i przyziemnym". Kurczowe trzymanie się zmysłowych form poznania nie jest dla duszy czymś naturalnym, a raczej jest skutkiem grzechu i zawężenia się naszej perspektywy. W naturalnej sytuacji dusza akceptowałaby niemożliwość uchwycenia własnej istoty (oraz Boga) bez kwestionowania ich realności, rozumiejąc po prostu, że są to byty niematerialne, których nie można zobaczyć czy doświadczyć jako „czegoś”. Nie można ich uchwycić. Upadek jednak powoduje, że realne wydaje nam się jedynie to, co możemy zobaczyć i dotknąć, co ma kształt, kolor, położenie w przestrzeni, ciężar etc.

Poczucie dezorientacji wynikające z upadku duszy, które ewokuje sugestywny obraz ślepców, nie tyle dotyczy jednak opisu obiektywnej rzeczywistości przedstawianej w pojęciowym, filozoficznym wywodzie, ile ilustruje samo doświadczenie wykonywania ćwiczenia duchowego. W dalszej bowiem części dialogu Makryna wykłada Grzegorzową koncepcję umysłu jako obrazu Boga i jako zwierciadła, w którym Bóg się odbija, niby słońce w maleńkim kawałku szkła. Tutaj pojawia się kolejna metafora, którą znajdujemy u Plotyna i pozostałych autorów platońskich. W Enneadach niepoznawalne centrum duszy jest podobieństwem i obrazem niepoznawalnego Jedna - Nysseńczyk idzie jeszcze dalej: umysł jest zwierciadłem Boga, a sama jego niepoznawalność jest odbiciem boskiej niepoznawalności.

Motyw zwierciadła, widzenia siebie oraz widzenia siebie w Bogu, wywodzi się z przypisywanego Platonowi dialogu Alkibiades I (132d-133c), w którym mowa jest o tym, że zobaczyć samego siebie albo własne oko można jedynie w zwierciadle czy innym tego rodzaju przedmiocie. To prowadzi Sokratesa do koncepcji samopoznania tego, co boskie (theion) w umyśle, poprzez wpatrywanie się w Boga (theos). Grzegorz łączy motyw poznawania siebie w zwierciadle $\mathrm{z}$ motywem umysłu jako obrazu Boga i uczestniczenia w Bogu, opisując już nie Boga jako zwierciadło, w którym umysł widzi siebie, 
ale nazywając umysł zwierciadłem, w którym widzimy samych siebie i Boga niejako jednym spojrzeniem.

W ćwiczeniu medytacji opisywanym w dialogu $O$ duszy Nysseńczyka przechodzimy drogę od pewności poznania umysłu jako poznającego (energeia) przez niemożność poznania jego istoty jako takiej (ousia) aż do ujęcia jego natury jako niematerialnej substancji uczestniczącej w boskiej Naturze. Co ciekawe, metafora zwierciadła nie do końca tu pasuje, bo Grzegorz nie mówi o świetle i widzeniu, jak Plotyn, ale o ciemności i ślepocie. Kiedy bowiem patrzymy na kawałek szkła, w którym odbija się słońce, widzimy słońce. Nie jest to słońce, które widzimy na niebie, ale jego obraz, który jest do oryginału podobny, bo ma wszystkie cechy słońca, mając jednak mniej bytu i mniej rzeczywistości. Czy jednak ciemność może się odbijać w zwierciadle? Grzegorz wydaje się właśnie o tym mówić. Skoro umysł badający swoją istotę staje się sam dla siebie ciemnością i ślepnie, patrząc w siebie, to badanie istoty Boga doprowadza nas również do ciemności i doświadczenia ślepoty i „macania”. Bóg odbija się w zwierciadle umysłu w taki sposób, że widzimy Go, patrząc w głąb samych siebie.

Tyle że - jak pokazuje Grzegorz - gdy patrzymy w nasz umysł, nic nie widzimy i to właśnie w tym „nic” widzimy - jak w zwierciadle - Boga, który jest dla naszego umysłu niczym, bo jest niepoznawalny. Nieuchwytność naszego umysłu, czyli to dezorientujące na początku poczucie „nie jest czymś", staje się pośrednim poznaniem Boga i Jego ukrytej istoty, która również „nie jest czymś”. Mamy tu więc implicite to paradoksalne i charakterystyczne dla mistyki Grzegorza przekonanie o tym, że widzenie Boga może być zupełnie realnym i fundamentalnie przemieniającym doświadczeniem, jednocześnie nie oferując żadnych pozytywnych treści poznawczych, które można by opisać w terminach naszego zmysłowego doświadczenia.

Można by zatem zapytać: Jak odróżnić Boga od umysłu, gdy się spogląda w siebie i nic się tam nie widzi? Rozwiązaniem Plotyna jest zniesienie różnicy w zjednoczeniu. Przejście od niepoznawalności naszego Ja do niepoznawalnego Jedna (od obrazu do pierwowzoru) opisane jest jako doświadczenie zaniknięcia różnicy między naszym Ja a Jednem: ,z tego powodu to widzenie jest niemożliwe do wysłowienia - jak bowiem mógłby ktoś Je obwieścić jako coś innego [od siebie], skoro, kiedy oglądał, nie zobaczył tam czegoś innego, ale coś, co było z nim jednym" (Enn. 6.9.10.19.21). Plotyn nie twierdzi, że nie ma ontologicznej różnicy między naszym Ja a Jednem, ale mówi o tym, że ta różnica zanika w doświadczeniu obecności Jedna.

Gdzie, zdaniem Grzegorza, jest różnica między „nic” umysłu i „nic” Boga? Nie chce on opisywać widzenia Boga w terminach zniesienia różnicy - pozostaje przy metaforze zwierciadła, odbijania, podobieństwa. Różnica jednak wydaje się wyłaniać w spekulatywnym opracowaniu tego doświadczenia, a nie 
w nim samym, gdyż polega na „małości” kawałka szkła, który odbija w sobie słońce. Słońce wydaje się jakby pomniejszone i mniej realne, choć ma wszystkie te cechy, które ma jego pierwowzór na niebie. Dlatego ciemne i ślepe samopoznanie umysłu jest widzeniem Boga, ale jakby Boga pomniejszonego do ludzkich rozmiarów, bo przecież dokonuje się ono w ludzkiej świadomości i to człowiek poznaje Boga, a nie Bóg - sam siebie. Jest to poznanie Jego samego, ale przecież właściwie - tylko nas w Nim uczestniczących. Ciemność odbija się w ciemności, nicość odzwierciedla w nicości, niewidzialne, boskie Słońce staje się dla nas w oczywisty sposób namacalne i zarazem zupełnie nieprzeniknione, podobnie jak nasz własny umysł.

\section{Augustyn z Hippony: umysł poznawalny}

Przedmiotem mojej refleksji nad samopoznaniem umysłu (mens) u Augustyna będzie księga dziesiąta dzieła $O$ Trójcy Świętej, którego druga część poświęcona jest w całości ludzkiej duszy i jej trynitarnej strukturze, która stanowi odbicie i uczestnictwo w boskiej Trójcy. W literaturze przedmiotu podkreśla się, że ta księga stanowi istotny wkład Augustyna w „teorię umysłu” i teorię samopoznania ${ }^{32}$. Jak zauważył już Willy Theiler, księga dziesiąta stanowi w zasadzie medytację nad tradycyjnym nakazem świątyni delfickiej: „poznaj samego siebie” (gnothi seauton), i wiązał ten materiał z zachowanym dziś jedynie fragmentarycznie traktatem Porfiriusza ${ }^{33}$. Również John Rist opisywał ten tekst jako „chrześcijańskie rozumienie tego sokratycznego aforyzmu" ${ }^{34}$. Uczeni wskazują również na podobieństwa czy nawiązania księgi dziesiątej De Trinitate do koncepcji Platona, Arystotelesa, stoików i, przede wszystkim, neoplatoników ${ }^{35}$. Jej rozmaite interpretacje zazwyczaj podkreślają związki między samopoznaniem a poznaniem Boga oraz wskazują na paradoksalny charakter tych związków ${ }^{36}$.

${ }^{32}$ G. O'Daly, Augustine's Philosophy of Mind, Berkeley-Los Angeles 1987, s. 207-216.

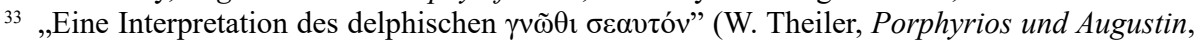
przedruk w: Forschungen zum Neu-Platonismus, Berlin 1966, s. 220).

34 J.M. Rist, Augustine: Ancient thought baptized, New York 1997, s. 87.

35 E. Booth, St. Augustine's «notitia sui» related to Aristotle and the early neo-Platonists, „Augustiniana” 27 (1977), ss. 70-132 \& 364-401, 28 (1978), ss. 183-221, 29 (1979), ss. 97-124. Por. J.M. Rist, Augustine: Ancient thought baptized.

${ }^{36}$ R. Williams, The Paradoxes of Self-Knowledge in the «De Trinitate», w: Collectanea Augustiniana: Signum Pietatis, red. J. Lienhard, E. Muller, R. Teske, New York 1993, s. 121-134; Augustine through the Ages. An Encyclopedia, red. A.D. Fitzgerald, Grand Rapids 1999, s.v. „De Trinitate"; L. Ayres, The Discipline of Self-Knowledge in Augustine's «De Trinitate» book X, w: The Passionate Intellect, red. L. Ayres, Brunswick-New York 1995; Augustine through the Ages. An Encyclopedia, S. Katz, s.v. „Seek-Find” i W.J. Hankey, s.v. „Mind”; P. Cary, Augustine's Invention of the Inner Self. The Legacy of a Christian Platonist, New York 2003, s. 63-69; P. Burnell, The 
Jak wskazywał Pierre Hadot, a później - Brian Stock, księga dziesiąta ma charakter ćwiczenia duchowego ${ }^{37}$, co sprawia, że warto ją zestawić z omówionym powyżej przeze mnie urywkiem dialogu $O$ duszy $i$ zmartwychwstaniu Grzegorza z Nyssy. Augustyn nie dąży tu wcale do uporządkowanego wykładu swoich poglądów na umysł i jego zdolność intuicyjnego wglądu we własną istotę, ale raczej prowadzi medytację i zachęca czytelnika do uczestnictwa w niej, co krok po kroku ma prowadzić do doświadczenia tego wglądu ${ }^{38}$. Podobieństwo między Augustynem a Grzegorzem tkwi też w tym, że biskup Hippony od razu wskazuje, że takie doświadczenie samopoznania ma w sobie coś głęboko paradoksalnego. Zaczynamy bowiem ćwiczenie od poszukiwania naszego własnego umysłu, tak jakby nie było to coś najbardziej oczywistego i najbardziej obecnego spośród wszystkich rzeczy istniejących. Augustyn traktuje tę oczywistą obecność umysłu jako coś, co nie wymaga dowodu, jest faktem doświadczenia, ale sięga też po jeden ze swoich ulubionych argumentów, zaczerpniętych z Platońskiego Fedona:

Cóż zatem umysł miłuje, gdy tak żarliwie poszukuje samego siebie, żeby siebie poznać, dopóki jest jeszcze sobie nie znany? Oto bowiem umysł szuka samego siebie, żeby siebie poznać i cały płonie tym pragnieniem. Miłuje zatem. Lecz co miłuje? Jeśli samego siebie, to jakże może siebie miłować, skoro nie zna jeszcze siebie i skoro nikt nie może kochać czegoś, czego nie zna? ${ }^{39}$

Augustyn odrzuca zatem możliwość, że umysł może nie znać samego siebie i od początku medytacji staje na stanowisku, opartym na doświadczeniu, że umysł zawsze, nieuchronnie, w sposób oczywisty poznaje sam siebie i zna siebie: „widzi bowiem siebie jakby wewnętrznie (intrinsecus)” (Trin. 10.5.7). O ile zatem u Grzegorza słyszymy o umyśle, który patrząc na siebie wewnętrznym wzrokiem, ślepnie i nic nie widzi, u Augustyna, jak się wydaje, mamy zupełnie odwrotną sytuację. Umysł widzi wewnętrznie sam siebie, spontanicznie i w każdym momencie. Co więcej, to samopoznanie umysłu wydaje się według Augustyna wręcz paradygmatem poznawalności - nic nie jest bardziej obecne, bardziej oczywiste, bardziej znane niż umysł sam dla siebie, bo przecież ani poznanie rzeczy zmysłowych, ani poznanie Boga, ani nawet poznanie

Augustinian Person, Washington 2005, s. 54-70; M.T. Clark, «De Trinitate», w: The Cambridge Companion to Augustine, red. E. Stump, N. Kretzmann, Cambridge 2005, s. 91-102; G.B. Matthews, Knowledge and illumination, w: The Cambridge Companion to Augustine, s. 171-185.

${ }^{37}$ Podejście Stocka jest swoiste, związane bardziej z ćwiczeniem czytania, tworzenia narracji na swój temat, niż introspekcyjnego wglądu w naturę umysłu (B. Stock, Augustine the Reader. Meditation, Self-Knowledge, and the Ethics of Interpretation, Cambridge-London 1998, s. 259-273).

${ }^{38}$ Por. E. Booth, St. Augustine's «notitia sui», s. 191; G. O'Daly, Augustine's Philosophy of the Mind, s. 207; P. Cary, Augustine's Invention of the Inner Self, s. 63-67.

${ }^{39}$ Trin. 10.3.5, Augustine, De Trinitate Libri XV, red. W.J. Mountain, Turnhout 1968. 
niezmysłowych Platońskich Form, nie zostało przez Augustyna opisane jako tak radykalna samoprzejrzystość.

$\mathrm{Z}$ tego płynie paradoksalna interpretacja delfickiego nakazu samopoznania, jedyna taka w antycznej tradycji filozoficznej:

Niech przeto nie stara się [umysł] poznać [cernere] siebie tak, jakby był nieobecny, lecz niech zabiega o to, by rozpoznać [discernere] siebie jako obecnego. Niech nie poznaje [cognoscat] siebie tak, jakby siebie już nie znał, ale niech od innych rzeczy, które zna, siebie odróżni [dignoscat, dosł. 'od-pozna']. Jak bowiem umysł może urzeczywistnić to, co słyszy: „Poznaj samego siebie”, jeśli już uprzednio nie wie, co to jest „poznaj” i co to jest „,siebie samego”? Jeśli zaś zna obie te rzeczy, zna i samego siebie. (Trin. 10.9.12)

Dla Augustyna nakaz delficki jest pozbawiony sensu, jeśli go rozumieć tradycyjnie i dosłownie, ponieważ sugeruje on, że musimy coś zrobić, żeby poznać siebie. Przecież całe Wyznania Augustyna zbudowane są na projekcie poznawania siebie jako czegoś, czego jeszcze nie znamy. Chodzi tu jednak o poznanie naszych myśli, uczuć, pragnień, nawyków etc., czyli nie istoty umysłu, ale różnych jego ,zawartości”. Istota umysłu jest zarysowana w Wyznaniach, choć Augustyn nie koncentruje się na badaniu tej istoty wewnętrznym wzrokiem. Mówi jednak w księdze dziesiątej tego dzieła o umyśle czy też „pamięci” (memoria), jak nazywa umysł, jako o aula ingens, „ogromnej sali”, w której znajdują się rozmaite rzeczy, umieszczone jakby w przestrzeni. Można więc powiedzieć, że o ile Wyznania są w głównej mierze badaniem tego, co znajduje się w tej przestrzeni umysłu, o tyle De Trinitate podejmuje próbę przyjrzenia się temu, czym jest ta przestrzeń sama w sobie.

Wracając do aporetyczności samopoznania: nie można poznać siebie, bo już i zawsze siebie znamy. Pewnym tropem jest to, że oczywistość tego samopoznania tkwi, jak pisze Augustyn, w wiedzy o tym, co to jest „poznać” i „samego siebie”. W niemal niezauważalny sposób wprowadza więc biskup Hippony aktywność poznawczą umysłu do jego istoty, oddalając się od tej linii medytacji, którą znajdujemy u Grzegorza. Poznanie samego siebie jest niemożliwe, bo już wiem, co to znaczy, że ja poznaję. Skoro poznaję, to jestem, a skoro jestem, to poznaję. Nie możemy więc nic zrobić, żeby zbliżyć się do samopoznania, raczej - nie możemy go uniknąć. Samo rozumienie nakazu poznania siebie pokazuje jego bezsensowność, ponieważ, zgodnie z Augustyńską teorią znaku wyłożoną we wczesnym De magistro (10.33-35; 11.36-38), żeby zrozumieć słowo, musimy mieć wcześniej doświadczenie rzeczy, którą to słowo oznacza. Nie możemy zatem zrozumieć słowa „Bóg”, nie doświadczając uprzednio Boga. W księdze dziesiątej De Trinitate Augustyn nie tyle mówi o uprzedniości poznania wobec rozumienia znaku, ile o jednoczesności. To 
nie nakaz delficki prowadzi mnie do samopoznania, to samopoznanie umożliwia mi zrozumienie nakazu, który następnie żąda ode mnie zrobienia tego, co właśnie robię, rozumiejąc nakaz:

Lecz gdy mówi się umysłowi: „Poznaj samego siebie”, w tym samym momencie, w którym rozumie, co się ma na myśli przez „samego siebie”, poznaje samego siebie, nie przez nic innego, jak tylko przez to, że jest dla siebie obecny. Jeśli zaś nie rozumie tego, co się tu ma na myśli, nie robi też tego [co się nakazuje]. Dlatego więc nakazuje się umysłowi, by uczynił to, co właśnie czyni, gdy sam ten nakaz pojmuje. (Trin. 10.9.12)

Znowu widzimy tutaj subtelne powiązanie istoty umysłu z poznaniem, w kontraście do surowego rozdzielenia ich u Grzegorza, gdzie szuka się istoty umysłu niejako abstrahując od jego aktywności. Tutaj obecność umysłu jest niejako właśnie poznawaniem i rozumieniem. Augustyn posługuje się przy tym tą samą metaforą, co Grzegorz, czyli metaforą zwierciadła. Gdy pyta, w jakim sensie zatem nakazuje się umysłowi, żeby poznał siebie, odpowiada:

Nie w takim sensie, jak się mówi człowiekowi: „Zobacz swoją twarz”, bo to możliwe jest tylko w zwierciadle. Albowiem twarz nasza nieobecna jest w polu naszego widzenia, ponieważ nie jest tam, gdzie możemy skierować wzrok. (Trin. 10.9.12)

Augustyn używa tutaj tej metafory jeszcze nie - jak Nysseńczyk - do opisania relacji uczestnictwa w Bogu, ale tak jak Plotyn w Enn. 5.8.11 - do podkreślania niemożliwości zobaczenia umysłu jako obiektu, który jest na zewnątrz niego. Pojawia się ona również w innych miejscach $O$ Trójcy Świę$t e j^{41} \mathrm{w}$ tym samym sensie: zwierciadło i odbicie twarzy lub oka stanowią tutaj ilustrację zewnętrzności charakterystycznej dla poznania zmysłowego, ale całkowicie zanikającej w samopoznaniu umysłu. Widać tu odwołanie do motywu z Alkibiadesa I. Nikt nie może zobaczyć swojej twarzy, a nawet jeśli spojrzy w zwierciadło, nie widzi przecież własnej twarzy, a jedynie jej odbicie, które jest obrazem i jest do pierwowzoru podobne pod absolutnie każdym względem, poza stopniem realności. W tym punkcie Augustyn spotyka się z Grzegorzem, pośrednio mówiąc o naszej ślepocie w badaniu istoty nas samych, ale - podobnie jak jego filozoficzny mistrz, Plotyn - unikając języka ciemności. Biskup Hippony wydaje się jednak nie mieć wątpliwości, że samopoznanie nie polega na tym, że widzimy swój umysł jako „coś”.

${ }^{40}$ Stock pisze: „Umysł poznaje siebie jako stan poznawania” (s. 268).

${ }^{41}$ Augustine, Trin. 9.3.3, 10.3.5, 14.6.8. 
Umysł zna siebie w pełni i bezpośrednio, ale nie poprzez figmentum, czyli wytwór, analogiczny do odbicia twarzy w zwierciadle. Nie jest on bowiem jak inne obiekty naszego poznania, ale jest bardzo szczególnym rodzajem obiektu, który jest „nie-obiektem”, ponieważ ujawnia się raczej w samej aktywności poznania niż w tym, co jest poznawane. Jednak właśnie dzięki temu, w każdym akcie poznania, poznania czegokolwiek, umysł jest w pełni obecny i przezroczysty sam dla siebie.

W świetle tych odkryć Augustyn zdumiewa się (i ma nadzieję, że czytelnik wraz z nim), jak to jest w ogóle możliwe, że ludziom wydaje się, że nie znają siebie i że powinni szukać siebie, żeby siebie poznać. Tak więc przy całej paradoksalności i przedziwnej interpretacji delfickiej maksymy jako niedorzecznej w dosłownym sensie, Augustyn akceptuje zdroworozsądkowy fakt, że nie jesteśmy jednak w pełni świadomi tego, że znamy swój umysł. Żeby wyjaśnić tę sprzeczność nieustannego samopoznania i powszechnego odczucia niewiedzy, Augustyn wprowadza pojęciowe rozróżnienie na zawsze obecną samoprzejrzystość umysłu, która jest fundamentalną i konieczną formą samopoznania, niejako wpisaną w samą istotę umysłu, oraz na pełne rozpoznanie tej samoprzejrzystości, które dokonuje się przez akt woli i zdaje się tym samym poznaniem, ale w pełni urzeczywistnionym.

Żeby wyjaśnić ten brak pełnej świadomości samopoznania, Augustyn sięga, podobnie jak Grzegorz, po neoplatońską koncepcję upadku duszy. Jesteśmy tak bardzo zafascynowani materialnymi obiektami i ich mentalnymi obrazami, że przez moc tej miłości zapominamy jakby o sobie i nie rozpoznajemy swojej natury. Skutkiem fascynacji materią i zmysłami, umysł popada $\mathrm{w}$ iluzoryczne myślenie o samym sobie jako o czymś zmysłowym i materialnym, wydaje się mu, że jest rzeczą wśród innych rzeczy i zaczyna widzieć siebie, tak jak widzimy twarz w zwierciadle, myląc przy tym odbicie z tym, co realne.

Dla Augustyna samopoznanie osiąga pełną i świadomą formę nie przez nabycie nowej wiedzy, ale raczej przez odrzucenie czegoś, co nam przeszkadza, czyli przez odróżnienie umysłu od tego, co umysłem nie jest, a zwłaszcza od tego, co jest zmysłowe i materialne, czyli - od obiektów naszej świadomości. „Poznaj siebie” interpretuje zatem Augustyn jako „bądź [świadomie] tym, czym jesteś”, a to z kolei jako: „zobacz, czym nie jesteś”. Jest to rozwój fundamentalnej intuicji Plotyna, że ten, kto mówi, patrząc w umysł, „nic tam nie ma, nic nie widzę”, nie jest tym samym, kto mówi: „widzę siebie”, gdyż pierwsze Ja operuje na poziomie zmysłowym, a drugie - na intelektualnym i duchowym. W stanie upadku nie mamy świadomości głębi swojego Ja i funkcjonujemy na powierzchownym, zmysłowym poziomie. Musimy podjąć ćwiczenia duchowe, żeby być świadomie tym, czym jesteśmy, poprzez uświadomienie sobie najpierw, czym nie jesteśmy. Chodzi tutaj o ćwiczenie odwracania uwagi od rzeczy, które nie są umysłem, i utrzymywania uwagi na 
samym umyśle, który jest zawsze obecny i przezroczysty dla siebie. A to, co poznawalne w umyśle, zdaniem Augustyna, to samo poznanie, toteż nie jest to stan poznawania „czegoś”, ale poznawania samego poznawania, tak jakbyśmy chcieli spojrzeć na widzenie raczej niż na to, co widzimy, albo stać się świadomymi samego doświadczenia bycia świadomymi.

U Augustyna pojawia się również moment przejścia od obrazu do pierwowzoru, czyli kontemplacji Boga w umyśle i przez umysł, który jest troisty i odzwierciedla w swoich stworzonych „trójcach” (np. pamięć, poznanie, wola) Trójcę Świętą. Choć ten wątek przewija się przez całą drugą część $O$ Trójcy Świętej, szczegółowo omawia Augustyn i niejako podsumowuje to zagadnienie w ostatniej księdze ${ }^{42}$. Co ciekawe, nie korzysta on tutaj ze standardowego tekstu z Rdz 1,26, który stanowi punkt wyjścia dla Grzegorza, ale sięga po św. Pawła, który mówi - zgodnie z tekstem łacińskim, posiadanym przez Augustyna - „Widzimy teraz w zwierciadle, w zagadce, wtedy zaś - twarzą w twarz" (1 Kor 13,12). Biskup Hippony wskazuje, że w zwierciadle ukazuje się obraz, toteż widzenie „W zwierciadle” (per speculum), oznacza widzenie pierwowzoru w jego obrazie, odzwierciedlonym na powierzchni zwierciadła, i powiada, że jest to wezwanie do tego, byśmy próbowali w medytacji oglądać Boga, którym nie jesteśmy w Jego jakby zwierciadlanym odbiciu, którym jesteśmy.

Przywołuje też Augustyn inny cytat ze św. Pawła, zgodnie ze swoją egzegetyczną metodą rozumienia fragmentów Pisma poprzez inne fragmenty Pisma, czyli zdanie z Drugiego Listu do Koryntian: „My zaś z odsłoniętą twarzą widząc jak w zwierciadle chwałę Pana, przekształcamy się w ten właśnie obraz z chwały w chwałę, przez Ducha Świętego" (2 Kor 3,18). Po tym następuje nieco zaskakująca dla współczesnego czytelnika dygresja filologiczna Augustyna, który wyjaśnia, jak należy rozumieć słowo speculantes, które pojawia się w tym zdaniu, i jak się ono ma do greckiego tekstu. W tej dygresji nie chodzi jednak o semantykę i problemy przekładu, ale o fundamenty medytacji samopoznania i jej związki z poznaniem Boga. Poświęćmy chwilę, żeby przyjrzeć się temu, z jakim kunsztem Augustyn w analizie jednego słowa odsłania złożoną naturę widzenia Boga w umyśle.

Wyjaśnia Augustyn, że słowo speculantes należy w Pawłowym stwierdzeniu rozumieć jako „widząc jak w zwierciadle” (per speculum videntes), a nie „ze strażnicy spoglądając w dal” (de specula prospicientes). Dodaje, że $\mathrm{w}$ języku greckim widzenie $\mathrm{w}$ zwierciadle $\mathrm{i}$ spoglądanie $\mathrm{w}$ dal ze strażnicy oznaczane są zupełnie niepodobnymi do siebie słowami, podczas gdy w łacinie speculum ('zwierciadło') i specula ('strażnica') brzmią podobnie. Biskup Hippony sugeruje, że łacinnicy narażają się tutaj na niebezpieczeństwo, od

${ }^{42}$ Augustine, Trin., 15.8.14-9.16. 
którego wolni są Grecy - czyli na mylne pojmowanie widzenia Boga jako spoglądania w dal ze strażnicy. Jeśli weźmiemy pod uwagę to, co Augustyn mówi o samopoznaniu we wcześniejszych księgach, jasne się stanie, do czego zmierza i na czym polega niebezpieczeństwo. Jeśli Boga chcemy widzieć jakby de specula prospicientes, czyli ze strażnicy, wtedy czynimy z Niego obiekt zewnętrzny wobec nas i daleki od nas. Słowo pro-spicio zawiera w sobie element wychodzenia poza siebie, na zewnątrz, podobnie jak projekcja, czyli wyrzucanie przed siebie. Ponadto ze strażnicy wypatruje się rzeczy, które są też niewidoczne, trudne do wyśledzenia, ukrywające się przed nami w oddali. Spoglądanie na Boga ze strażnicy zatem reprezentuje według Augustyna próbę poznania Boga przez świadomość zmysłową, która ujmuje swoje obiekty, niejako wybiegając przed siebie i poza siebie ku czemuś innemu niż ona sama. Towarzyszy temu odczucie oddzielenia od Boga.

W przeciwieństwie do tego uzewnętrzniającego sposobu patrzenia, Augustyn proponuje widzenie $\mathrm{w}$ zwierciadle, przy czym to umysł jest zwierciadłem, które spogląda samo w siebie i widzi tam odbity obraz Boga, którym $\mathrm{w}$ istocie jest. Mamy tutaj zupełnie inny sposób patrzenia, charakterystyczny dla medytacji samopoznania, czyli zwrot ku sobie samemu i ujmowanie siebie nie jako zewnętrznego obiektu (czyli nie tak, jak widzimy swoją twarz w zwierciadle), ale zupełnie inaczej, w jedności z samym sobą. Ponieważ zaś umysł, jak wcześniej pokazywał Augustyn, widzi siebie jako poznanie, które nie może być zobaczone jako „coś”, to właśnie poznająca natura umysłu wydaje się odbiciem Boga w umyśle.

Ta interpretacja zostaje następnie pogłębiona przez Augustyna, gdy wnika on w dalszą część wersetu św. Pawła. Należy rozumieć tutaj słowo speculantes jako oglądanie w zwierciadle, czyli bez uzewnętrznienia obiektu widzenia, ponieważ apostoł dodaje zaraz, że gdy oglądamy chwałę Pana, przekształcamy się w ten właśnie obraz. Jaki obraz? W obraz Boga, którym jesteśmy, jak Augustyn wcześniej pokazywał - przekształcamy się w ten właśnie obraz, który oglądamy $\mathrm{w}$ zwierciadle naszego umysłu. $\mathrm{O}$ ile jesteśmy obrazem Boga, o tyle jesteśmy też Jego chwałą, na dowód czego przytacza też Augustyn inny cytat: „Mąż bowiem nie powinien zasłaniać swojej głowy, bo jest obrazem i chwałą Boga” (1 Kor 11,7). Przez „męża” rozumie tu Augustyn najwyższą lub najgłębszą część ludzkiej duszy, samą istotę umysłu.

W tym miejscu znowu mamy moment filologiczny: Augustyn wnika w sens słowa „przekształcać się” (transformare), które rozumie jako przechodzenie od jednego kształtu do drugiego, od jednej formy do drugiej, i wyjaśnia, że to przejście, które już u Plotyna mieliśmy jako kulminacyjny moment medytacyjnego wznoszenia się do Boga, oznacza przejście od kształtu ciemnego do jaśniejącego. Kształtem ciemnym jest obraz Boga taki, jaki istnieje w człowieku z racji samego faktu bycia człowiekiem, nawet jeśli grzech 
go zaciemnił. Upadek duszy nie niszczy więc tego zwierciadła, którym jest umysł, i dlatego, jak Augustyn podkreśla, nawet upadły człowiek jest chwałą Boga. Przekształcenie się ,z chwały w chwałę” oznacza przejście od „,kształtu zniekształconego" (a deformi forma) w „kształt kształtny”, czyli piękny (in formam formosam), jest - jak podkreśla Paweł - dziełem łaski i Ducha Świętego w nas.

Augustyn mówi tu więc o tym, że w procesie medytacji przechodzimy jakby od nieświadomego bycia obrazem Boga i odbijania go w sobie jak w zwierciadle, do świadomego i jasnego bycia zwierciadłem, w którym odbijamy i kontemplujemy nasz Pierwowzór. Jest to z jednej strony równoznaczne z przejściem od stanu grzechu do stanu łaski, a z drugiej, jak dodaje Augustyn, od wiary do widzenia. Biskup Hippony nie pozostawia możliwości widzenia Boga wyłącznie zbawionym. Jego interpretacja św. Pawła zmierza ku temu, że wprawdzie widzenie twarzą w twarz możliwe będzie dopiero po śmierci, ale już w tym życiu możemy przejść od wiary w Boga do oglądania Boga, tyle że w obrębie widzenia w zwierciadle naszego umysłu, przez obraz. To przejście od nieświadomego do świadomego odzwierciedlania w sobie Boga Augustyn rozumie jako proces upodabniania się do Boga - sięgając zarazem po Platońską definicję filozofii jako homoiosis theoi z Teajteta (176a) i po Pierwszy List św. Jana: „będziemy do Niego podobni, gdy zobaczymy Go takim, jakim jest" (1 J 3,2). Warto zwrócić uwagę, że kontekst tego cytatu jest bezwzględnie eschatologiczny, dotyczy oglądania twarzą w twarz, a Augustyn odnosi go tutaj także do kontemplacji Boga w tym jeszcze życiu, w Jego obrazie.

Medytacja samopoznania jest zatem dla Augustyna uświadamianiem sobie tego, że nasz umysł odbija Boga jak zwierciadło, i oglądaniem Go w zwierciadle naszego Ja. Omawiając księgę dziesiątą, zwróciłem uwagę, że dla Augustyna paradoksalność samopoznania polega na tym, że jednocześnie jest ono czymś oczywistym i czymś, co trzeba w sobie urzeczywistnić. Tutaj ten paradoks powraca, gdy Augustyn zastanawia się nad znaczeniem sformułowania „w zagadce” (in aenigmate). Objaśnia, że zagadka w retoryce jest rodzajem alegorii, a alegoria ma miejsce wtedy, kiedy jedna rzecz oznacza druga i do niej odsyła. Znowu mamy więc do czynienia z obrazem, który, podobnie jak alegoria czy symbol, odsyła do swojego Pierwowzoru, w którym uczestniczy i który odzwierciedla. Zagadka jest jednak takim typem alegorii, który nie jest od razu widoczny, ale wymaga wysiłku intelektualnego, żeby w obrazie dostrzec, czego właściwie jest odbiciem. „Zagadka jest ciemną alegorią” (aenigma est obscura allegoria) mówi Augustyn, co natychmiast przenosi nas do wcześniejszego odkrycia, że proces medytacji jest przejściem od obrazu ciemnego do obrazu jaśniejącego. O ile zwierciadło reprezentuje obraz Boga, o tyle zagadka - podobieństwo do Niego, przy czym podobieństwo dla Augustyna jest czymś dynamicznym, jest upodobnianiem się, czyli aktualizacją 
istniejącego $\mathrm{w}$ nas obrazu i jakby jego rozświetleniem dzięki naszej uwadze i świadomości. Święty Paweł mówi więc jednym tchem, że widzimy teraz „,W zwierciadle w zagadce”, żeby pokazać, że wznoszenie się do Boga w medytacji jest procesem, który wymaga w tym życiu ćwiczenia i czasu.

Natychmiast jednak Augustyn powraca do fundamentalnego paradoksu: „Nie zabrzmiałoby tu zaiste słowo «zagadka», gdyby widzenie było łatwe. A oto większa jeszcze zagadka: jakże możemy nie widzieć, skoro nie możemy nie widzieć?!" (Trin. 15.9.16). Mamy tu być może echo Plotyna (Enn. 5.5.8), który mówi, że paradoksem jest to, że Jedno przychodzi do nas i ukazuje się nam nagle, choć przecież jest nieustannie obecne i w istocie rzeczy nie może przyjść ani odejść, ukazać się ani zniknąć nam z oczu. Plotyn mówi, że doświadczeniu ,ukazania się" Jednego towarzyszy w pierwszym momencie zaskoczenie: ,zdumiewające, jak nie przyszedłszy, jest obecny i jak nie będąc nigdzie, nigdzie nie ma [miejsca], gdzie nie jest. Można się więc w ten sposób na początku zdumiewać, ale ktoś, kto Go doświadcza, zdumiałby się raczej, gdyby coś przeciwnego miało miejsce" (5.5.8.23-27).

Augustyn również zachęca czytelnika do przeżycia zdziwienia tym, jak możemy nagle w medytacji zacząć widzieć Boga, skoro nie możemy uniknąć widzenia Go, podobnie jak nie możemy uniknąć oczywistego poznania własnego umysłu. W tym punkcie samopoznanie i poznanie Boga w jego zwierciadle stają się jednym oczywistym zarazem i nieustannym, ale, paradoksalnie, wymagającym czasu i wysiłku ćwiczeniem dochodzenia do tego, co zawsze już widzimy. Widzimy bowiem Boga, widząc swoje myślenie - a kto, pyta Augustyn, nie widzi własnego myślenia, czyli poznawczej aktywności umysłu, która jest tym właśnie, co całkowicie i zawsze oczywiste? „Kto go nie widzi i kto je widzi?" - pyta, a paradoks tkwi w tym, że myślenie jest w istocie widzeniem, świadomością duszy. A myślenie własnego myślenia, uświadomienie sobie faktu bycia świadomym, jest czymś zarazem zawsze obecnym i wymagającym urzeczywistnienia. W tym właśnie myśleniu myślenia czy widzeniu widzenia odbija się Bóg jak w zwierciadle i w ten sposób możemy Go poznać. Co jest zatem prawdziwą zagadką? Bóg, który dla większości z nas wydaje się nieobecny i odległy, czy nasza ślepota, gdy skąpani w Jego blasku, twierdzimy, że jest noc?

Droga medytacji u Augustyna przebiega zatem w ogólnej swojej strukturze, podobnie jak u Grzegorza, od poznania samej aktywności poznawczej umysłu jako oczywistej przez niemożność poznania jego istoty jako czegoś (niemożność zobaczenia swojej twarzy) aż po zrozumienie umysłu jako obrazu Boga i zwierciadła, w którym można Go kontemplować. 


\section{Dwa aspekty intuicyjnego samopoznania}

U obu ojców Kościoła mamy zatem przekonanie o wadze poznania siebie, o możliwości badania umysłu wewnętrznym wzrokiem oraz o istnieniu ćwiczeń duchowych, które prowadzą do samopoznania. U obu możemy wyróżnić nawet trzy podobne momenty, to znaczy poznanie poznawczego działania umysłu, jego istoty oraz pojęciową, obiektywną spekulację na temat jego natury i relacji do Stwórcy. To, co jest ciekawe, to fakt, że droga Grzegorza i Augustyna wydają się kończyć sprzecznymi ze sobą konkluzjami. Grzegorz twierdzi, że nie możemy poznać umysłu i Boga, a Augustyn - że poznanie nie tyle nie jest niemożliwe, ile jest niemożliwe do uniknięcia, bo jest czymś oczywistym.

Grzegorz z Nyssy opisuje istotę umysłu jako „nieuchwytną” (akataleptos) z tego powodu, że nie ma ona żadnych możliwych do zaobserwowania jakości, w przeciwieństwie do rzeczy materialnych. W związku z tym ćwiczenie wpatrywania się w umysł wywołuje doświadczenie ,ślepnięcia” i niewidzenia niczego. Zarazem jednak filozoficzna interpretacja tego doświadczenia w żaden sposób nie kwestionuje substancjalnego istnienia umysłu, ponieważ Grzegorz jest pewny, że umysł, jako ten, który poszukuje swojej istoty i nie widzi jej, realnie istnieje. Poznawalna jest również jego aktywność (energeia) - to, że umysł poznaje i że jest czymś poznającym.

Gdy Nysseńczyk wspomina o uczestnictwie umysłu w Bogu i o jego zwierciadlanej naturze, która odbija Bożą naturę, używa tradycyjnego, neoplatońskiego obrazu Słońca i światła, które wydają się przeczyć doświadczeniu ślepoty, ciemności i niepoznawalności. Skoro Bóg, który jest nieuchwytny, przypomina jaśniejące Słońce, które odbija się w kawałku szkła (w umyśle), okazuje się, że dla Grzegorza metafora ciemności i niewidzenia jest ściśle spleciona z metaforą światła i widzenia. W egzegetycznym Życiu Mojżesza Grzegorz użyje słynnego wyrażenia ,świetlista ciemność" (lampros gnophos) w opisie doświadczenia obecności Boga ${ }^{43}$, natomiast wydaje się, że również w dialogu $O$ duszy $i$ zmartwychwstaniu przyjmuje on taką właśnie perspektywę. Nieuchwytność, czyli niepoznawalność umysłu jako czegoś, co wydaje się niczym, jest nie tylko doświadczeniem „,iemnym”, ale i ,jasnym”, ,świetlistym", czyli - coś się tutaj ukazuje. Wydaje się, że tym, co świetliste, jest działanie, aktywność poznawcza, a tym, co ciemne - istota i substancja umysłu, choć nawet czyste wpatrywanie się w ciemność umysłu i ciemność Boga mają w sobie coś niewyrażalnie świetlistego, co nie jest ich działaniem.

${ }^{43}$ Gregorii Nysseni, De vita Moysis 87.10, w: Gregorii Nysseni Opera, t. VII, cz. I, red. H. Musirillo, Leiden 1991. 
Grzegorz sugeruje też, że przyczyną doświadczenia ślepoty czy „nicości" umysłu jest nadmierne przywiązanie do rzeczy materialnych i nawykowe utożsamianie poznania i widzenia z poznaniem i widzeniem czegoś, co ma zmysłowe cechy. Nie sięga jednak po Plotyńską koncepcję zjednoczenia przez zniesienie różnicy między Jednem a duszą, ale zarazem wydaje się korzystać swobodnie z Plotyńskich opisów dezorientującego doświadczenia pozbawionego jakichkolwiek przedmiotów świadomości. O ile niemożliwe jest pozytywne doświadczenie istoty umysłu, dostępne jest jej doświadczenie negatywne w tym sensie, że ujawnia się ona jako coś, co nie jest podobne do niczego innego, i jako coś, co nie jest materialne ani zmysłowe.

Jeśli chodzi o Augustyna, to jest dla niego oczywiste, że umysł jest najlepiej poznawalną rzeczą z wszystkiego, co jest w zasięgu naszego doświadczenia, i posługuje się językiem obecności, poznania, rozumienia, widzenia itd. Sięga więc raczej po Plotyńskie opisy Intelektu jako czystego intuicyjnego samopoznania za pośrednictwem inteligibilnych Form niż do wykraczających poza Intelekt doświadczeń Jedna przez niewiedzę. Widać tutaj charakterystyczne rozwidlenie chrześcijańskiej myśli na Wschodzie i Zachodzie - Wschód podkreślać będzie z reguły niepoznawalność, Zachód - poznawalność istoty Boga.

U Augustyna $\mathrm{w}$ ogóle prawie nie pojawia się motyw ciemności i w tym sensie jest on wiernym uczniem Plotyna, gdyż zarówno umysł, jak i Bóg, są zawsze i tylko światłem i poznaniem, nawet jeśli niemożliwe jest zobaczenie tego poznania jako czegoś, jako obiektu. Z równą bowiem mocą biskup Hippony odrzuca pomysł, że moglibyśmy nasz umysł zobaczyć tak po prostu, jak swoją twarz w zwierciadle, czyli jako „coś” oddzielonego od nas. Jego medytacja w księdze dziesiątej i w innych miejscach O Trójcy Świętej skłania się ku widzeniu umysłu raczej jako aktywności poznania niż jako istoty tego czegoś, co poznaje albo - do widzenia istoty przez aktywność. Wydaje się, że o ile w interpretacji filozoficznej Augustyn niewątpliwie uważa umysł za substancję, która jest sama dla siebie przejrzysta i ma moc świadomości i poznawania, o tyle w medytacyjnym doświadczeniu opisuje samopoznanie raczej jako aktywność i proces, jako coś dynamicznego bardziej niż „rzecz”, którą się intelektualnie widzi.

Ciemność pojawia się w księdze piętnastej, gdy Augustyn próbuje uchwycić paradoks samopoznania i poznania Boga w Jego obrazie, polegający na tym, że w jakimś sensie nie widzimy w pełni naszego umysłu, który w nieuchronny sposób musimy widzieć, i dlatego potrzebujemy ćwiczeń duchowych, żeby to widzenie w pełni uświadomić sobie. O ile jednak u Grzegorza niepoznawalność Boga odbija się $\mathrm{w}$ niepoznawalności umysłu, o tyle u Augustyna to światło i chwała Boga jaśnieją odbite w zwierciadle naszego Ja. Ciemność symbolizuje raczej spowodowaną upadkiem nieświadomość tej 
oczywistości niż samą jakość tego poznania. Podobnie jednak jak u Grzegorza, umysł jest zwierciadłem i widzimy Boga nie wtedy, gdy szukamy Go gdzieś poza nami, ale wtedy, kiedy wpatrujemy się w samych siebie i kiedy urzeczywistniając naszą samoświadomość, przechodzimy od zaciemnionego grzechem zapomnienia o naszej chwale do pełnego oglądania jej blasku w zwierciadle naszego myślenia. Brak pełnej świadomości tego blasku jest skutkiem upadku i grzechu - nieco podobnie jak u Grzegorza - ponieważ wyraża się w niewiedzy tego, czym różni się substancja duchowa od materialnej. Rozglądanie się ze strażnicy stanowi dla Augustyna metaforę, która symbolizuje manowce medytacji, w której szukamy siebie i Boga jako obiektów zewnętrznych wobec naszego Ja, zamiast zwrócić się do siebie, rozumiejąc, że blask Boga odbitego w umyśle nie jest i nie może stać się „czymś”, co będziemy oglądać poza nami.

Powyższe rozważania prowadzą do wniosku, że sprzeczność między Grzegorzem a Augustynem w opisie samopoznania jest pozorna. Wynika ona nie tylko z tego, że pierwszy chętnie korzysta z metaforyki ciemności i ślepoty oraz z apofatycznych wątków Plotyna, a drugi koncentruje się na tradycyjnie platońskich symbolach światła i bardziej katafatycznych motywach Ennead, ale też z innego rozłożenia akcentów w medytacji i w doktrynie. Podobnie jak Grzegorz, Augustyn opisuje doświadczenie umysłu w medytacji jako czegoś, co nie jest „czymś” i czego nie można zobaczyć, podobnie jak zobaczyć nie można własnej twarzy. Grzegorz jednak o wiele bardziej koncentruje się na tym wątku, stara się wejść głęboko w doświadczenie dezorientacji i ślepoty umysłu odnośnie do własnej istoty, podczas gdy Augustyna interesuje, co innego, to znaczy - fakt, że umysł odsłania się nam jako aktywność poznania i to w sposób oczywisty widzimy, gdy cokolwiek poznajemy. Obaj ojcowie jednak zgadzają się, że trudności w samopoznaniu wynikają z tego, że nawyki upadłej duszy skłaniają ją do tego, by uważać umysł za coś zmysłowego i za rzecz wśród innych materialnych rzeczy. To nawykowe przekonanie można usunąć przez praktykę medytacji wpatrywania się w umysł, która prowadzi nas ostatecznie do kontemplacji Boga odbitego w zwierciadle umysłu, który w Nim uczestniczy.

\section{Wnioski: Czy istnieją punkty styczne?}

Po pierwsze, zarówno tradycja chrześcijańska, jak i buddyjska, wydają się zgadzać co do tego, że wartościowa jest praktyka wpatrywania się we własny umysł i dążenia do intuicyjnego uchwycenia jego natury tak, jak się ona jawi w medytacyjnym doświadczeniu. $\mathrm{W}$ tej praktyce pojawiają się dwa typy doświadczeń, które są zarazem dwiema zasadniczymi cechami naszego 
doświadczenia umysłu: doświadczenie niemożności poznania istoty umysłu oraz doświadczenie oczywistości tego, że umysł jest poznający i przez to dla samego siebie przejrzysty. Obie tradycje odwołują się też niezależnie do metafor widzenia własnego oka czy twarzy w zwierciadle.

Po drugie, w obu tradycjach obok ścieżki doświadczeniowej i intuicyjnej istnieje ścieżka spekulatywna, w której poprzez pojęcia próbuje się opisać doświadczalnie nieuchwytną naturę umysłu. Tutaj wspólnym elementem jest metoda aferetyczna, w której zdobywamy wiedzę o tym, czym umysł jest, poznając, czym nie jest, czyli odróżniając go od obiektów, które się mu jawią, a które - przeciwnie do niego - mają jakości zmysłowe i materialne, takie jak kształt, kolor, rozciągłość, ciężar, twardość, umiejscowienie, czas trwania itd. Umysł nie jest niczym z tego wszystkiego.

Po trzecie, w chrześcijaństwie i buddyzmie istnieje przekonanie o tym, że kondycja człowieka naznaczona jest głębokim poczuciem zła, które określa się na rozmaite sposoby - upadek, grzech, cierpienie, samsara, oddzielenie, niewiedza itd. Jednocześnie, obie tradycje są przekonane, że oferują wyzwolenie się z tej kondycji poprzez szereg środków duchowych, które mają charakter soteriologiczny i terapeutyczny. Niewiedza o tym, czym jest umysł, i mylenie go z tym, czym nie jest, i w chrześcijańskim platonizmie (lecz nie w tomizmie), i w buddyzmie, jest skutkiem stanu upadku. Nie jest to sytuacja naturalna.

Dwie zasadnicze i chyba nieprzekraczalne różnice, które dzielą te dwie tradycje tkwią w metafizyce i pojęciu substancji czy bytu, ponieważ chrześcijaństwo zakłada i musi zakładać istnienie wielości ontologicznie możliwych do wyodrębnienia bytów, które wyłaniają się z Boga jako nieskończonego Źródła bytu, podczas gdy buddyzm neguje istnienie jakiekolwiek substancji. Doktryna „braku jaźni” (anatta) głosi bowiem, że nie ma niczego, co by miało niezależne, substancjalne istnienie. Nie ma też bytu absolutnego, od którego wszystko inne byłoby zależne, a raczej sieć współzależnie powstających i nawzajem się warunkujących bytów względnych ontologicznie, które powstają i zanikają od zawsze i bez końca. Nie istnieje w związku z tym osoba jako Boecjuszowa rationalis substantiae individua substantia, a umysł w buddyzmie tybetańskim nie jest uważany za byt osobowy. Nauczyciele buddyjscy rozumieją „osobę” jako złożenie i zjawisko, podczas gdy w neoplatońskiej tradycji elementem konstytutywnym osoby jest po prostu intelekt, czyli poznanie, a wola stanowi nieodłączny aspekt natury poznającej. Do istoty ogólnie rozpatrywanej osoby nie należą zaś z konieczności ciało, wspomnienia, pragnienia, emocje, myślenie pojęciowe itd., choć jest to integralna część osoby ludzkiej, która składa się z ciała oraz duszy, która sama w sobie ma władze nie tylko intelektualne, ale zmysłowe i związane ściśle z ciałem.

Te metafizyczne i antropologiczne różnice wydają się zakorzenione głębiej, w odmiennym stosunku do samej obiektywnej spekulacji filozoficznej - o ile 
w chrześcijaństwie istnieje optymistyczne przekonanie o tym, że rozum ludzki może przez pojęciowe wnioskowanie dojść do poznania prawdy o rzeczywistości, naturze umysłu, Boga i świata materialnego, o tyle w buddyzmie prawda jest ostatecznie przedmiotem bezpośredniego doświadczenia, które wykracza poza dyskurs pojęciowy, a sam ten dyskurs ma o wiele mniejsze znaczenie. Powoduje to, że pewne problemy i argumenty filozofii chrześcijańskiej dla buddyzmu są pozbawione sensu jako teoretyczne, oderwane od naglącej egzystencjalnej sytuacji człowieka, który potrzebuje wyzwolenia i wybawienia od cierpienia.

\title{
SELF-KNOWLEDGE OF THE MIND IN CHRISTIANITY AND BUdDHISM
}

\begin{abstract}
The article compares the understanding of self-knowledge of the mind in Tibetan Buddhism (in the schools of Mahamudra and Dzogchen) with the ancient, Platonic Christian philosophy. It argues that in both traditions there are two aspects of the experience of self-knowledge: the impossibility of grasping the mind as an object and the ceaseless, unavoidable awareness of the mind's cognitive activity. The first of those aspects is called by the Tibetan tradition "emptiness", while the second - lucidity of the mind's nature. In Gregory of Nyssa and Augustine of Hippo we can see a difference of accent in terms of the significance of those two motifs, but it seems that both philosophers understand self-knowledge in a very similar way. Recognizing those two aspects is what brings the Buddhist and the Western traditions close to each other, while a fundamental difference between them lies in the fact that in the latter, selfknowledge of the mind opens a path to the experience of the infinite mind of God, of which the first is an image, while in Buddhism the concept of God does not appear at all. Individual self-knowledge is treated as the experience of the nature of one, universal and absolute mind.
\end{abstract}

Keywords: self-knowledge, Tibetan Buddhism, Christian Platonism, meditation

Słowa kluczowe: samopoznanie, buddyzm tybetański, chrześcijański platonizm, medytacja

\section{BIBLIOGRAFIA}

Augustine, De Trinitate Libri XV, red. W.J. Mountain, Turnhout 1968.

Arraj J., God, zen, and the intuition of being, http://www.innerexplorations.com/catew/3.html [dostęp: 22.06.2020]. 
Arraj J., Mysticism, metaphysics and Maritain, https://www.innerexplorations.com/catchmeta/1.html [dostęp: 22.06.2020].

Ayres L., The Discipline of Self-Knowledge in Augustine's De Trinitate book X, w: The Passionate Intellect, red. L. Ayres, Brunswick-New York 1995, s. 261-296.

Barnes M.R., Divine unity and the divided self: Gregory of Nyssa'a trinitarian theology in its psychological context, w: Re-thinking Gregory of Nyssa, red. S. Coakley, Blackwell-Oxford 2003, s. 45-66.

Booth E., St. Augustine's 'notitia sui' related to Aristotle and the early neo-Platonists, „Augustiniana" 27 (1977), s. 70-132 i 364-401, 28 (1978), s. 183-221, 29 (1979), s. 97-124.

Burnell P., The Augustinian Person, Washington 2005.

Carabine D., Gregory of Nyssa on the Incomprehensibility of God, w: The relationship between Neoplatonism and Christianity, red. T. Finan, V. Twomey, Dublin 1992, s. 79-99.

Cary P., Augustine's Invention of the Inner Self. The Legacy of a Christian Platonist, New York 2003.

Christianity in the Crucible of East-West Dialogue, Cheloquin 2001, https://www.innerexplorations. com/catew/christia.html [dostęp: 22.06.2020].

Christian Faith and Greek Philosophy in Late Anitquity, red. L. Wickham, C. Bammel, Leiden 1993.

Clark M.T., De Trinitate, w: The Cambridge Companion to Augustine, red. E. Stump, N. Kretzmann, Cambridge 2005, s. 91-102.

Critical Questions in Christian Contemplative Practice, Cheloquin 2007, https://www.innerexplorations.com/catchspmys/Critical.html [dostęp: 22.06.2020].

Daniélou J., Platonisme et théologie mystique. Doctrine spirituelle de Saint Grégoire de Nysse, Aubier 1944.

De Trinitate, w: Augustine through the Ages. An Encyclopedia, red. A.D. Fitzgerald, Grand Rapids 1999.

Gregorii Nysseni, De anima et resurrectione, w: Gregorii Nysseni Opera, t. III, cz. III, red. A. Spira, Leiden 2014.

Gregorii Nysseni Opera, t. III, cz. III, red. A. Spira, Leiden 2014.

Gregorii Nysseni Opera, t. VII, cz. I, red. H. Musirillo, Leiden 1991.

Gregor von Nyssa und die Philosophie: Zweites Internationales Kolloquium Gregor von Nyssa, red. H. Doerrie, M. Altenburger, U. Schramm, Leiden 1976.

Grzegorz z Nyssy, De vita Moysis, w: Gregorii Nysseni Opera, t. VII, cz. I, red. H. Musirillo, Leiden 1991.

Hadot P., Czym jest filozofia starożytna?, tłum. P. Domański, Kęty 2000.

Hadot P., Filozofia jako ćwiczenie duchowe, tłum. P. Domański, Kęty 2003.

Hadot P., Twierdza wewnętrzna: wprowadzenie do "Rozmyślań» Marka Aureliusza, thum. P. Domański, Kęty 2004.

Hankey W.J., Mind, w: Augustine through the Ages. An Encyclopedia, red. A.D. Fitzgerald, S. Katz, Grand Rapids 1999.

Hart D.B., The Mirror of the Infinite: Gregory of Nyssa on the vestigia Trinitatis, w: Re-thinking Gregory of Nyssa, red. S. Coakley, Oxford 2003, s. 117-121.

Katz S., Seek-Find, w: Augustine through the Ages. An Encyclopedia, red. A.D. Fitzgerald.

Ladner G.B., The Philosophical Anthropology of Saint Gregory of Nyssa, „Dumbarton Oaks Papers", 12 (1958), s. 59-94.

Laird M., Gregory of Nyssa and the Grasp of Faith. Union, Knowledge, and Divine Presence, New York 2004.

Low J., Być tu i teraz. «Zwierciadło jasnego znaczenia», terma dzogczen Nudana Dordże z komentarzem Jamesa Low, thum. J. Janiszewska-Rain, Kraków 2005.

Łapiński K., Ananeou seauton: «Rozmyślania» Marka Aureliusza w kontekście grecko-rzymskiej praktyki filozoficznej, Warszawa 2018. 
Matthews G.B., Knowledge and illumination, w: The Cambridge Companion to Augustine, red. E. Stump, N. Kretzmann, Cambridge 2005, s. 171-185.

O’Daly G., Augustine's Philosophy of Mind, Berkeley-Los Angeles 1987.

Peroli E., Gregory of Nyssa and the Neoplatonic Doctrine of the Soul, „Vigiliae Christianae” 51, No. 2 (May, 1997), s. 117-139.

Plotinus, Enneads, thum. i red. A.H. Armstrong, Cambridge-London 1966-1988.

Re-thinking Gregory of Nyssa, red. S. Coakley, Oxford 2003.

Rist J.M., Augustine: Ancient thought baptized, New York 1997.

Rist J.M., Plotinus and Christian philosophy, w: Cambridge Companion to Plotinus, red. L.P. Gerson, Cambridge 1996, s. 386-414.

Roth C.P., Platonic and Pauline Elements in the Ascent of the Soul in Gregory of Nyssa's Dialogue on the Soul and Resurrection, „Vigiliae Christianae” 46, No. 1 (Mar., 1992), s. 20-30.

Siemieniewski A., Kiwek M., Chrześcijańska medytacja monologiczna: źródła i aktualne pytania, Wrocław 2013.

Stead G.C., Ontology and Terminology in Gregory of Nyssa, w: Gregor von Nyssa und die Philosophie: Zweites Internationales Kolloquium Gregor von Nyssa, red. H. Doerrie, M. Altenburger, U. Schramm, Leiden 1976, s. 107-127.

Stock B., Augustine the Reader. Meditation, Self-Knowledge, and the Ethics of Interpretation, Cambridge-London 1998.

Stróżyński M., Filozofia jako terapia w pismach Marka Aureliusza, Plotyna i Augustyna, Poznań 2014.

Stróżyński M., Spiritual Exercise in the Proem to Augustine's Confessions, „Augustinian Studies” 49, 2 (2018), s. 221-245.

The Cambridge Companion to Augustine, red. E. Stump, N. Kretzmann, Cambridge 2005.

Theiler W., Porphyrios und Augustin, w: W. Theiler, Forschungen zum Neu-Platonismus, Berlin 1966, s. 160-251.

The Passionate Intellect, red. L. Ayres, Brunswick-New York 1995.

The Relationship between Neoplatonism and Christianity, red. T. Finan, V. Twomey, Dublin 1992.

Therapeia, askesis, meditatio: praktyczny wymiar filozofii $w$ starożytności $i$ średniowieczu, red. K. Łapiński, R. Pawlik, R. Tichy, Warszawa 2017.

Thrangu Rinpocze K., Pointing Out the Dharmakaya. Teachings On the Ninth Karmapa's Text, New York 2003.

Williams R., Macrina's Deathbed Revisited: Gregory of Nyssa on Mind and Passion, w: Christian Faith and Greek Philosophy in Late Anitquity, red. L. Wickham, C. Bammel, Leiden 1993, s. 227-246.

Williams R., The Paradoxes of Self-Knowledge in the De Trinitate, w: Collectanea Augustiniana: Signum Pietatis, red. J. Lienhard, E. Muller, R. Teske, New York 1993, s. 121-134. 